Gemma Caballer Albareda

gemmacaballer@ub.edu

CRAI Biblioteca de Reserva de la Universitat de Barcelona

Laura Moré

laura.more@udg.edu

Biblioteca. Universitat de Girona

Imma Muxella

immaculada.muxella@upf.edu

CRAI Biblioteca Campus Ciutadella. Universitat Pompeu Fabra

Anna Nicolau Payàs

anicolau@bnc.cat

Biblioteca de Catalunya

\title{
BIBLIOTEQUES PATRIMONIALS A CATALUNYA (2018-2019)
}

\section{BIBLIOTECAS PATRIMONIALES EN CATALUÑA (2018-2019)}

\section{HERITAGE LIBRARIES IN CATALONIA (2018-2019)}




\section{RESUM | RESUMEN | ABSTRACT}

En aquesta edició de I'ANUARI destaquen un parell de tendències en l'àmbit de les biblioteques i centres patrimonials. La primera és la innovació, amb exemples d'experiències en què els bibliotecaris surten de la seva zona de confort per col-laborar amb altres investigadors al mateix nivell, aportant la seva expertesa i potenciant la utilització de les col-leccions que custodien, i generant continguts. Parlant també d'innovació, les humanitats digitals es consoliden amb múltiples projectes o grups de treball o espais de creació, com els digital labs, que contribueixen a democratitzar el patrimoni. La segona tendència que apuntem és la reutilització del patrimoni digital. La digitalització ha estat una bona eina de difusió del patrimoni, però els usos encara són molt limitats i se circumscriuen majoritàriament en els àmbits acadèmics i erudits. Cal trobar nous usos del patrimoni digital i això segurament requerirà de partenariats amb agents molt diversos, que siguem més flexibles i creatius, i sobretot que hi hagi un marc legal clar que ho reguli. Finalment, l'article repassa les principals novetats en matèria de formació, recerca, difusió i publicacions al llarg del bienni 2018-2019.

En esta edición del ANUARI destacan dos tendencias en el ámbito de las bibliotecas y centros patrimoniales. La primera es la innovación, con ejemplos de experiencias en las que los bibliotecarios salen de su zona de confort para colaborar con otros investigadores en el mismo nivel, aportando su experiencia, potenciando la utilización de las colecciones que custodian y generando contenidos. Hablando también de innovación, las humanidades digitales se consolidan con múltiples proyectos o grupos de trabajo o espacios de creación, como los digital labs, que contribuyen a democratizar el patrimonio. La segunda tendencia que apuntamos es la reutilización del patrimonio digital. La digitalización ha sido una buena herramienta de difusión del patrimonio, pero los usos todavía son muy limitados y se circunscriben mayoritariamente en los ámbitos académicos y eruditos. Hay que encontrar nuevos usos del patrimonio digital y esto seguramente requerirá de partenariados con agentes muy diversos, que seamos más flexibles y creativos, y sobre todo que haya un marco legal claro que lo regule. Finalmente, el artículo repasa las principales novedades en materia de formación, investigación, difusión y publicaciones a lo largo del bienio 2018 hasta 2019.

This edition of the ANUARI focuses on recent trends in the area of libraries and heritage centres. The first trend is innovation, with examples of experiences in which librarians abandon their comfort zone to work with other researchers at the same level, contributing their expertise, promoting the use of their collections, and generating new materials. The Digital Humanities are consolidating their position in the area of innovation with the creation of multiple projects, work groups, and creative spaces such as digital labs that contribute to the democratization of heritage. The second trend highlighted is the reuse of digital heritage. Digitization has been a good tool for disseminating heritage, but its uses are still very limited and are mostly confined to the academic and scholarly fields. New applications of digital heritage need to be found. This is likely to involve partnerships with very diverse agents and will require higher levels of flexibility and creativity. The establishment of a clear legal framework to regulate their uses is also mandatory. Finally, the article reviews the main developments in training, research, dissemination and publications in 2018 and 2019. 
PARAULES CLAU:

Biblioteques patrimonials, Centres patrimonials, Arxius, Patrimoni, Preservació

PALABRAS CLAVE:

28/06/2020

Bibliotecas patrimoniales, Centros patrimoniales, Archivos, Patrimonio, Preservación

ACCEPTAT

KEYWORDS:

27/07/2020

Heritage libraries, Heritage archives, Heritage, Preservation 


\section{INTRODUCCIO}

Si en el número anterior de l'ANuARI us parlàvem de l'auge de les col-leccions especials i de la contribució de les TIC a una major visibilització dels fons especials, així com de la irrupció de les humanitats digitals com una nova disciplina que arrencava amb molta força, enguany volem parlar de les tendències que s'han anat perfilant en aquests darrers dos anys. En primer lloc, parlarem d'innovació, un terme molt en voga en l'àmbit de les biblioteques, sempre en transformació constant per adaptar-se als canvis de l'entorn i a les noves necessitats dels usuaris, però que potser, aplicat a biblioteques patrimonials, a priori, pot sonar contradictori, però no ho és gens.

Una altra tendència que d'entrada pot semblar molt trencadora és la reutilització del patrimoni digital. Després de dues dècades digitalitzant per preservar i difondre el patrimoni que custodien, les biblioteques han de fer un salt endavant i apostar per la reutilització del patrimoni digital. Aquest és un gran repte al qual s'enfronten i que no està exempt d'obstacles, sobretot en el terreny legal, però cal trobar nous usos per al patrimoni i teixir noves aliances, a través de la col-laboració entre institucions culturals de diferents àmbits - les GLAM (galeries, libraries, archives, museums)- i potser fins i tot transcendir les fronteres, atès que és un problema generalitzat arreu d'Europa.

Per acabar, us presentem les principals novetats, esdeveniments i publicacions relacionades amb el patrimoni bibliogràfic que han vist la llum en el transcurs del bienni 2018-2019.

\section{NOVES TENDÈNCIES EN L'ÀMBIT DE LES BIBLIOTEQUES I CENTRES PATRIMONIALS}

\subsection{Innovació i biblioteques patrimonials: és possible?}

Si en el darrer article sobre l'estat de les biblioteques patrimonials vàrem incidir en la rellevància que estaven prenent les humanitats digitals, creiem que en aquesta nova edició hem d'aturar-nos també en un concepte que ha pres una embranzida important en tots els àmbits de la nostra societat: la innovació. Tal com s'apuntava a Document: butlletí del Col-legi Oficial de Bibliotecaris-Documentalistes de Catalunya a finals de 2019, quin hauria de ser el sentit de la innovació a les biblioteques i, en el nostre cas concret, a les biblioteques patrimonials? Podem afirmar que totes les iniciatives
Després de dues dècades digitalitzant per preservar $i$

difondre el

patrimoni que

custodien, les

biblioteques han de

fer un salt endavant

i apostar per la

reutilització del

patrimoni digital 
innovadores que s'estan portant a terme en el nostre àmbit tenen com a fita facilitar l'accés al coneixement al ciutadà amb l'ambiciós objectiu final inherent a la nostra voluntat de servei de millorar la societat?

Evidentment, aquest concepte d'innovació cobreix un espectre d'actuacions molt ampli i podem observar com les biblioteques patrimonials porten a terme accions d'índole ben diversa intentant visibilitzar les seves col-leccions i aproximar els seus fons a la societat. Existeix una voluntat clara de treure els fons dels dipòsits i posar-los a l'abast de tothom promovent aquestes col-leccions úniques a través d'exposicions, de propostes d'estudi, de projectes col-laboratius, etc. Cada biblioteca intenta treure partit de la seva situació $\mathrm{i}$ jugar amb encert tots els elements que li són donats. En el cas de les biblioteques patrimonials lligades a institucions d'educació superior, s'ha apostat per aprofitar el marc universitari per oferir també l'experiència, assessorament $\mathrm{i}$ productes $\mathrm{i}$ serveis que fomentin l'erudició i la creació, com la realització d'exposicions i jornades en col-laboració amb professors o investigadors; oferir propostes de TFG i de TFM a partir del fons propi o propostes de col-laboracions basades en l'aprenentatge basat en projectes, etc. Un cas clar és el del CRAI Biblioteca de Reserva de la UB, que el 2017 va decidir replantejar-se el paper dins l'entorn universitari i va apostar per donar una empenta a tot allò relatiu al suport a la docència, reinventant-se en certa manera, ja que el suport a la docència "estàndard» que es donava en el marc de les biblioteques universitàries de la Universitat de Barcelona no s'ajustava a les seves característiques. En aquest sentit, la innovació va anar de la mà de la voluntat de donar resposta a alguns dels canvis i les apostes que s'estaven produint en la seva institució d'educació superior: pretenia millorar la formació dels estudiants de determinades disciplines potenciant el paper de les fonts històriques i les experiències professionalitzadores a través d'un dels eixos clau cap a on estaven derivant molts dels estudis universitaris impartits per la UB, l'aprenentatge basat en projectes. La biblioteca va decidir repensar el seu paper per tal d'esdevenir un element actiu i postular-se com un eix vertebrador de la docència, col-laborant així en habilitar l'èxit acadèmic dels estudiants, que és un dels objectius clau de la institució. A la pàgina web del CRAI Biblioteca de Reserva s'ofereix accés al catàleg de propostes de TFG i TFM basats en el seu fons $\mathrm{i}$, a través del seu blog, s'ofereix accés a notícies al voltant de TFG i TFM sorgits arran d'aquesta iniciativa o a la promoció de l'aprenentatge basat en projectes.

Estretament lligat amb la innovació també s'està veient clar que cada cop cal tenir més present la col-laboració, un element estratègic si desitgem que les experiències desenvolupades siguin exitoses. El benefici és doble, ja que acostar-nos a nous colllectius obrirà el nostre àmbit d'acció $i$, a més, ens permetrà aproximar-nos al nostre fons des de nous punts de vista i necessitats. L'objectiu, en molts casos, serà assolir col-laboracions amb els nostres interlocutors d'igual a igual. En el cas d'entorns universitaris - com esmentàvem abans-, el salt, com destaquen alguns autors com Harvell i Ball (2017), està a deixar de donar suport a la recerca - o a altres activitats - i esdevenir colllaboradors de facto. Esdevenir colllaboradors també ens pot ajudar a obtenir més visibilitat, tant de la nostra feina com de les nostres
Podem observar

com les biblioteques patrimonials porten a terme accions d'índole ben diversa intentant visibilitzar les seves col-leccions i aproximar els seus fons a la societat

La col/laboració, que cada cop cal tenir més present, ens permet acostar-nos a nous col-lectius i obrir el nostre àmbit d'acció i aproximarnos al nostre fons des de nous punts de vista i necessitats 
col-leccions. En aquest sentit, considerem que cal reivindicar i posicionarnos clarament en aquest nou context ple de possibilitats i deixar a la cuneta aquest rol tradicionalment subsidiari i d'anar a remolc que hem exercit en projectes que anaven més enllà del nostre àmbit tradicional d'actuació. Innovar també significa prendre partit $\mathrm{i}$ protagonisme en àmbits que tradicionalment no eren els nostres però en els quals ara podem tenir un paper clau. Cal mostrar confiança en les nostres possibilitats i saber vendre tot el que podem aportar. En aquest sentit, diversos estudis demostren que el paper de les biblioteques en l'àmbit de les humanitats digitals és clau i, en el cas de les biblioteques patrimonials, podem esdevenir clau aportant continguts $i$ aproximacions a aquests estudis que, fins ara, han restat invisibles als ulls de molts investigadors. Això comportarà noves formes de treballar, però si un collectiu ha demostrat saber adaptar-se als canvis de l'entorn, creiem que aquest ha estat precisament el nostre. Només ens falta adonar-nos que tenim la possibilitat de fer un salt important. Si tradicionalment la literatura al voltant de biblioteques $i$ humanitats digitals ha tendit a focalitzar el punt de mira en com les biblioteques poden donar suport a les humanitats digitals, com si aquesta fos una forma més de suport a la docència, Harvell i Ball destaquen que cal apostar per un nou model de col-laboració o associació, que incorpori el treball que es porta a terme als laboratoris d'humanitats digitals dins de la biblioteca i viceversa. La UAB ha estat pionera en la instal-lació d'un laboratori d'humanitats digitals (HDLab) dins de la seva biblioteca, concretament dins la sala de revistes. Els membres de LIBER en la seva publicació Open a GLAM lab exposen que els GLAM labs, siguin virtuals o bé físics, haurien de ser els espais que permetessin posar en contacte els creadors, investigadors i la societat en general, amb els recursos digitals que custodien les institucions $i$ la tecnologia per explotar-los. En aquest triangle el rol dels professionals de les biblioteques no és només proveir els materials digitals, sinó també $\mathrm{i}$ sobretot, propiciar les interaccions entre els diversos investigadors $i$ creadors per tal de fomentar la creativitat a l'hora de reutilitzar els materials des d'enfocaments i objectius diversos, i molt sovint, multidisciplinaris.

Com es pot comprovar, no podem pensar en innovació sense submergir-nos en el camp de les humanitats digitals. Tal com assenyala Anglada, ens trobem en un moment en què el futur està en construcció, així que més enllà de seguir pràctiques professionals «institucionalitzades» des de fa anys, ara "no hi ha altra "recepta" que la d'arremangar-se i posar-s'hi» (Anglada, 2019). I és precisament això el que està passant amb les humanitats digitals. El 2018 va crear-se dins el CSUC el Grup de Treball en Humanitats Digitals, amb representants de diverses institucions consorciades. Aquest grup de treball té com a primer objectiu copsar quin tipus de recerca s'està fent en l'àmbit de les humanitats digitals dins les institucions per tal d'identificar de quina manera hi poden contribuir les biblioteques i centres de recursos i millorar la formació dels professionals per encarar els nous reptes que plantegen les humanitats digitals.

En l'àmbit de la conservació i preservació, la Biblioteca de Catalunya i el director general del CSUC signaren, el juny del 2019, el primer conveni de
Esdevenir

colllaboradors

també ens pot

ajudar a obtenir més

visibilitat, tant de la

nostra feina com de

les nostres

col-leccions

Cal apostar per un

nou model de

col-laboració o

associació, que

incorpori el treball

que es porta a terme

als laboratoris

d'humanitats

digitals dins de la

biblioteca i viceversa

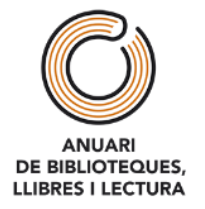


l'Estat espanyol per liderar un projecte de preservació digital distribuïda, que contribueixi a la colllaboració entre plataformes per tal de recollir i conservar els recursos digitals amb dipòsit legal en virtut del Reial decret $635 / 2015$, de 10 de juliol, pel qual es regula el dipòsit legal de les publicacions en línia. Per tal d'unificar i normalitzar el mètode de transferència de la producció digital des dels editors a la Biblioteca de Catalunya, pel que fa als recursos electrònics, la Biblioteca ha desenvolupat un nou mòdul web. També convé destacar la iniciativa, empresa conjuntament amb el MNAC, el Museu Jaume Morera de Lleida i I'AHCB, de contribuir a la conservació de fons d'arxius gràfics, també sobre el còmic en paral-lel amb el projecte Patrimoni d'Editors i Editats - amb l'ajuda també d'iniciatives privades que sumen, a l'espera que el Museu del Còmic de Badalona esdevingui una institució que vertebri aquest projecte d'àmbit nacional.

Per anar concloent aquesta reflexió al voltant de la innovació, a principi de 2020 Dídac Martínez feia algunes consideracions sobre un concepte que havia introduït el sociòleg Ray Oldenburg -el Tercer lloc- que defensava la necessitat d'un tercer lloc social, per complementar el primer lloc (l'espai familiar) i el segon (l'espai laboral). Traspassant els límits de les biblioteques universitàries a les quals fa referència Martínez, podem parlar de les biblioteques patrimonials també com a «tercer lloc»? Les seves característiques les acaben revestint d'una aura d'exclusivitat que estem intentant difuminar amb un esforç important de democratització de la cultura i de fer "comunitat». En aquest sentit, i malgrat les particularitats evidents de treballar amb un fons tan sensible, moltes institucions estan potenciant les seves biblioteques patrimonials com a centres culturals organitzant exposicions, conferències, debats, etc. En definitiva, programes d'activitats sobre temes actuals amb l'objectiu que esdevinguin també llocs de trobada. Un exemple clar d'aquestes dinàmiques és l'organització d'exposicions que està organitzant el CRAI Biblioteca de Reserva de la Universitat de Barcelona. Si uns anys enrere el personal de la Biblioteca era qui organitzava la majoria d'exposicions, cada cop pren més pes que s'organitzin en collaboració amb algun departament, professor o investigador de la institució que participi en l'organització d'alguna jornada vinculada a l'exposició.

Com s'indica en l'article citat inicialment (Harvell; Ball, 2017), la tecnologia està provocant que les barreres entre uns serveis $i$ unes professions es vagin difuminant, que les biblioteques -físiques i virtuals- es converteixen en espais de lleure i de coneixement, en espais de trobada cada cop més participatius. Pensem a innovar, ens reinventem, però l'essència continua sent la mateixa: facilitar l'accés a la informació i al coneixement per millorar la societat, una societat que canvia, com nosaltres també hem de fer-ho. Els processos de transformació i innovació han d'estar totalment incrustats a l'ADN de la nostra professió.
Malgrat les

particularitats

evidents de treballar

amb un fons tan

sensible, moltes

institucions estan

potenciant les seves

biblioteques

patrimonials 


\subsection{Nous usos del patrimoni digital}

L'impuls a la digitalització del patrimoni cultural continua a l'horitzó de les polítiques governamentals, com ho demostra la seva inclusió explícita al tercer eix del Pla de Govern de la Generalitat de Catalunya (2018-21): biblioteques, I'Agenda 2030, ciberseguretat, Pla de cultura digital. Però després de gairebé dues dècades digitalitzant el patrimoni bibliogràfic que custodien les nostres biblioteques, en els darrers anys s'ha evidenciat que aquests esforços no són suficients i que és necessari anar més enllà.

Els projectes de digitalització van néixer amb un doble objectiu: es tractava, per una banda, de preservar el patrimoni, evitant sempre que fos possible la manipulació directa dels materials i creant còpies que n'asseguressin la perdurabilitat en el temps; per l'altra, de fer-ne difusió, visibilitzar-lo i potenciar-ne la consulta com a fonts primàries per a la recerca per contribuir a generar nou coneixement. Ara, amb una certa perspectiva $\mathrm{i}$ gràcies a l'informe Report on ENUMERATE Core Survey 4, corresponent a l'any 2017, sabem que aproximadament només un $17 \%$ dels materials de biblioteques estan digitalitzats, mentre que un $50 \%$ resten encara pendents de digitalització i el $33 \%$ restant no és susceptible de ser-ho (Nauta; Heuvel; Teunisse, 2017). A més, la Recomanació de la Comissió Europea 2011/11/EU i el seu informe de seguiment d'implementació corresponent al període 2015-2017 mostren que l'accés que es dona al patrimoni digital és insuficient i que cal apostar per la seva reutilització, assegurant que les obres de domini públic mantenen aquest estatus després de ser digitalitzades. Concretament, la Recomanació fa una crida als estats membres en el punt 5 :

«Improve access to and use of digitised cultural material that is in the public domain by:

a) ensuring that material in the public domain remains in the public domain after digitisation;

$b$ ) promoting the widest possible access to digitised public domain material as well as the widest possible reuse of the material for non-commercial and commercial purposes;

c) taking measures to limit the use of intrusive watermarks or other visual protection measures that reduce the usability of the digitised public domain material; [...]»

Òbviament, els documents subjectes a drets d'autor o les obres òrfenes, com també els drets d'autor que s'apliquen a les metadades dels documents digitalitzats, constitueixen obstacles per a l'accés $i$, sobretot, la seva reutilització. Segons l'informe d'ENUMERATE, només el $46 \%$ dels continguts digitalitzats es troben en domini públic i només el $58 \%$ de les metadades ho són també. De totes maneres, les obres de domini públic també presenten limitacions, com es desprèn de l'informe de seguiment de la Recomanació, que n'identifica les principals: la por a la pèrdua de control sobre les col-leccions digitalitzades $i$ els possibles ingressos que poden generar; la manca d'un marc legal clar sobre l'estatus dels documents de domini públic un cop digitalitzats i de les metadades corresponents, i,
Els projectes de digitalització van néixer amb un doble objectiu: per una banda, de preservar el patrimoni, i per l'altra, de fer-ne difusió, visibilitzar-lo i potenciar-ne la consulta com a fonts primàries per a la recerca 
finalment, els possibles drets dels agents que intervenen en els processos de digitalització sobre la seva producció digital (sobretot en el cas de fotògrafs).

Pel que fa als usos, cal distingir entre usos no comercials i comercials. En el primer cas, els usos més freqüents són els relacionats amb l'activitat acadèmica - tant de recerca com de docència- $\mathrm{i}$ altres usos educatius; també $\mathrm{s}^{\prime} \mathrm{hi}$ troben experiències com les col-laboracions amb la Viquipèdia o les exposicions virtuals.

Per contra, els usos comercials són molt menys habituals i normalment estan relacionats amb les mateixes institucions que custodien el patrimoni o amb empreses/institucions del sector creatiu. Un bon exemple seria la creació de marxandatge basat en les pròpies col-leccions, una pràctica molt habitual en els museus i no tant en les biblioteques. En aquest sentit, al nostre país tenim els exemples del CRAI Biblioteca de Reserva de la UB, la col-lecció de punts de llibre dels exlibris dels Fons Especials de la UdG o les diverses publicacions de la Biblioteca de Catalunya, només per citar-ne alguns.

En tot cas, el que és segur és que els projectes més ambiciosos i a més gran escala requereixen $d$ 'aliances $o$ partenariats amb altres institucions culturals o amb empreses del sector privat (normalment tecnològiques o financeres) que puguin aportar la seva expertesa i/o els seus recursos.

El maig de 2019 DARIAH, infraestructura europea de recerca en art i humanitats, va organitzar, dins el seu Annual Event 2019, un taller sobre el tema dels usos del patrimoni amb el títol «Cultural Heritage Reuse Cases: Facilitating the Exchange of Perspectives between Heritage Professionals and Researchers». El taller es va centrar a mostrar casos de reutilització del patrimoni, tant des de la perspectiva dels professionals de la gestió del patrimoni com dels acadèmics dels àmbits de les humanitats i l'art. Això evidencia el neguit del sector per resoldre aquesta qüestió.

Al nostre país, aquesta tendència ja començava a apuntar-se el 2016, quan I'Ateneu Barcelonès va dedicar-hi la seva jornada bianual, que ja vam citar en I'ANUARI anterior, sota el títol "Les vides i (re)vides del patrimoni: reutilització i futur». La trencadora ponència inaugural va presentar el projecte de la Koninklijke Bibliotheek dels Països Baixos, que va decidir obrir la biblioteca digital per a la reutilització dels continguts sense cap mena de restriccions - pel que fa a les obres subjectes a drets d'autor, van negociarne l'ús amb finalitats científiques. Alguns dels usos fruit del projecte van ser: projectes d'humanitats digitals per part de la comunitat universitària; l'estudi del comportament de cerca dels usuaris a través de l'estudi dels logs de les seves interaccions amb el web de la biblioteca per part dels tècnics informàtics; col·laboracions diverses amb Viquipèdia - com la cessió de fotografies de domini públic o amb llicència Creative Commons per il-lustrar els articles, o acollir un viquipedista resident durant uns mesos perquè fes articles basats en els continguts de la biblioteca-, o usos comercials com la creació d'una base de dades legal a partir de la
Els projectes més ambiciosos i a més gran escala requereixen

d'aliances o partenariats amb altres institucions culturals o amb empreses del sector privat que puguin aportar la seva expertesa i/o els seus recursos 
documentació legislativa. La conclusió contundent de Lotte Wilms va ser que les institucions només poden conèixer la utilitat de les collleccions que custodien mitjançant l'ús que en fan els usuaris.

En aquest sentit, i per donar resposta a l'ús creixent que es fa de la seva col-lecció, el novembre de 2019 el CRAl Biblioteca del Pavelló de la República de la Universitat de Barcelona va fer públic el seu banc d'imatges -que actualment conté una col-lecció de més de deu mil imatges sobre la Segona República, la Guerra Civil, l'exili, el franquisme i la transició-, que va néixer fruit de la necessitat d'utilitzar una eina que fes més àgil la gestió de les fonts documentals i al mateix temps posar-les a disposició de tothom. Aquesta eina és, actualment, un excel-lent exemple que facilita la reutilització del patrimoni a casa nostra.

\section{DIFUSIÓ I TIC EN EL MARC DE LES BIBLIOTEQUES PATRIMONIALS}

\subsection{Treball en xarxa i presència a internet}

En aquest bienni, alguns nous centres patrimonials s'han incorporat al CSUC ampliant la xarxa, com ara la biblioteca de la Fundació Carl Faust - Jardí Botànic Marimurtra (Blanes) que ha quedat vinculada a la Universitat de Girona i que permet consultar la seva biblioteca particular, o la biblioteca del Centre d'Informació i Documentació del Memorial Democràtic.

La digitalització dels fons arriba també a biblioteques que, independentment de la naturalesa i règim d'accés, es van obrint a la ciutadania. N'és un exemple la biblioteca de la Fundació Uriach, al polígon industrial de Palau-solità, que va sortir a la premsa presentant una col-lecció de prop de dotze mil llibres d'història de la medicina de totes les èpoques.

Un exemple de treball en xarxa i en col-laboració seria el de les biblioteques públiques de la Diputació de Barcelona: en el catàleg de serveis per al 2019, es marca com a objectius la catalogació dels fons especials que custodien, juntament amb la digitalització i difusió dels seus fons locals i patrimonials.

El PolDoc és un recurs professional molt interessant, promogut per la Facultat d'Informació i Mitjans Audiovisuals de la UB, que recull informes, polítiques i protocols relatius a la gestió de fons i col-leccions i que permet posar en comú experiències alhora que serveix de referència per elaborarne. És un projecte d'àmbit espanyol i, entre els centres que hi participen, hi ha biblioteques catalanes, idioma en el qual també està disponible. En formen part biblioteques de tot tipus i arxius.
La digitalització dels fons arriba també a biblioteques que, independentment de la naturalesa i règim d'accés, es van obrint a la ciutadania 
Pel que fa a les eines de recuperació de la informació, el 2019, el CRAI de la UB va estrenar el cercador Cercabib -encara en fase beta- a tot el fons del CRAI, al marge del suport, la tipologia o la ubicació del recurs. Es va decidir mantenir també l'accés al catàleg clàssic del CRAI de la UB, que ofereix un scope -visualització- específica per al fons antic, de gran utilitat per als usuaris. Destaquem també l'Explora $B C$, el nou cercador de continguts de la Biblioteca de Catalunya que agrupa en una única eina corporativa bases de dades a les quals abans només es podia cercar per separat. Un altre centre de documentació, en aquest cas d'un museu, ha presentat una nova eina de cerca: I'OMNIMUS és un portal que permet explorar de manera transversal diverses bases de dades del Museu de Ciències Naturals de Barcelona, entre les quals hi ha la guia de col-leccions museogràfiques, l'inventari de l'arxiu històric i el catàleg de la biblioteca i de la mediateca. La Biblioteca disposa d'una considerable col-lecció de patrimoni bibliogràfic catalogada.

\subsection{Eines de gestió i projectes de digitalització}

La Biblioteca de Catalunya és un dels socis collaboradors del portal Europeana, la biblioteca multimèdia digital europea. A més de proporcionar continguts, actua com a intermediària entre Europeana i altres institucions catalanes a través dels repositoris digitals: Memòria Digital de Catalunya (MDC); Cartoteca Digital, de I'Institut Cartogràfic i Geològic de Catalunya; Trencadís, de la Diputació de Barcelona; BiPaDi, de la Universitat de Barcelona, i Simurg, del CSIC (que ha assolit la plena integració el passat 2018). L'Ateneu Barcelonès, per exemple, hi ha publicat el seu fons d'imatges de la Primera Guerra Mundial.

La Memòria Digital de Catalunya ha incorporat al llarg del 2018 vuit noves col-leccions: Col-lecció de Poesia Catalana BGRF; els nous manuscrits de la Càtedra Gaudí i l'arxiu fotogràfic disponibles al portal del Fons Antic de la Biblioteca EEBE (UPC); Fons Germanor d'Orfeons de Catalunya, i Programes Cor de Cambra del Palau de la Música Catalana (CDOC); Incunables de la Biblioteca Pública Episcopal del Seminari de Barcelona (URL); Legislació Històrica de la Corona d'Aragó (ICAB); Fons Miniprint Internacional de Cadaqués (BC), i Epistolari de Víctor Balaguer (1842-1900) (Biblioteca Museu Víctor Balaguer). A més, s'han fet millores tècniques com ara la migració del repositori al núvol o l'actualització del seu programari base, el CONTENTdm, implementant una nova interfície més atractiva i millorada quant a usabilitat. Finalment, els registres de la MDC han estat inclosos a l'EBSCO Discovery Service.

Durant el 2019, les incorporacions han estat de setze col-leccions noves: Fons Documental - El Centre i Fons Fotogràfic - El Centre (CMIG), Fons Periodístic Jaume Guillamet (UPF), Fons Emili Vendrell i Ibars, Fons Josep Rodoreda i Santigós, Fons Joan Baptista Lambert i Caminal i Fons Joan Pujol Mateu (CDOC), Fons Daniel Vilaró Rius (primera col-lecció de la URV), Fons Digital Ricard Giralt Miracle, i Mapes i Plànols del Pavelló de la República (UB), i Fons Josep Ribot, Dibuixos d'Àngel Puigmiquel, Dibuixos d'Antoni
La Memòria Digital de Catalunya ha incorporat al llarg del bienni vint-i-quatre noves colleccions que superen les de l'anterior i

consoliden encara més aquest recurs 
Roca Maristany, Fons Enric Cervelló, Dibuixos de Pablo Ramírez, i Alexandre Galí. Història de les Institucions i del Moviment Cultural a Catalunya (BC). Celebrem també la incorporació de la Reial Acadèmia de Medicina de Catalunya al projecte.

Les incorporacions d'aquests darrers dos anys superen les del bienni anterior i consoliden encara més aquest recurs. Les xifres de l'MDC a finals de 2019 són molt rellevants: més de dos milions d'imatges/documents, cent seixanta-nou col-leccions i trenta-sis institucions participants.

Durant el període 2018-2019, el CRAI Biblioteca de la Universitat de Barcelona ha continuat amb la seva aposta per BiPaDi (Biblioteca Patrimonial Digital de la UB), i ha incrementat aquest portal amb sis noves col-leccions: Belles Arts i Arts Gràfiques; Biografies; Ciències de la Terra; Espectacles, Esports i Jocs; Gastronomia i Cuina; Música; Pedagogia i Educació; Psicologia i Ciències Afins; Ramon Llull i Lul-lisme, i Textos Sagrats. El CRAI Biblioteca de Reserva, per la seva banda, ha endegat aquest bienni dues col/leccions especials: Papers Decorats i Manuscrits Recuperats per Marià Aguiló.

Al Ilarg d'aquest bienni, la Biblioteca de la Universitat de Girona ha incorporat al seu repositori DUGi Fons Especials la col-lecció Pergamins del Monestir de Sant Daniel, fruit d'un conveni de colllaboració a tres bandes entre el Monestir, la Universitat i I'Institut Català de Recerca en Patrimoni Cultural. S'ha digitalitzat i publicat el manuscrit de la gramàtica catalana de Pau Cardellach de 1840 i també s'han digitalitzat cartes, diaris i llibretes de treball de Joan Ferraté que properament estaran disponibles al repositori.

A les biblioteques de la Universitat Autònoma de Barcelona, s'han incorporat noranta-set documents nous a la Biblioteca Digital d'Història de l'Art Hispànic. Pel que fa al projecte de l'Arxiu Històric de la Societat del Gran Teatre del Liceu, s'ha seguit treballant en la digitalització i publicació de la documentació amb noves col-leccions, entre les quals destaquen: Cartells; Escenografies; Fotografies; Partitures, i Programes de Mà. L'Arxiu consta d'onze mil cent documents (dades de 2018). També s'ha finalitzat la digitalització i publicació del Fons Pedro Pascual, s'ha seguit treballant en la Memòria Càrnia Digital i en la Col-lecció de Cartells Polítics Digitals, i s'ha creat la Col·lecció d'Adhesius Polítics.

La Universitat Politècnica de Catalunya ha redactat el 2018 el projecte de I'Arxiu Digital Gaudí, una plataforma digital d'accés obert que té com a objectiu difondre els fons patrimonials de la Càtedra Gaudí i l'ETSAB, així com anar incorporant continguts relacionats amb Antoni Gaudí i la seva obra. S'han digitalitzat 2.630 plànols i dibuixos de l'Arxiu Gràfic i la Càtedra Gaudí i s'han escanejat 4.138 plaques fotogràfiques de vidre.

La Universitat de Lleida ha digitalitzat al llarg d'aquest període una part del Fons Josep Vallverdú i del Fons Samuel Gili i Gaya. També, s'ha digitalitzat un document inèdit del Fons Humbert Torres sobre la metapsíquica. Com a novetats del seu portal de Fons Especials, han migrat el servidor de
Les biblioteques universitàries han continuat amb els repositoris $i$ projectes que fa anys que funcionen 
preservació al núvol, han canviat el format de les fitxes de fons en forma de biblioguies i han creat una col-lecció que recull tots els inventaris de fons especials. Al repositori del fons musical de la COPE s'ha seguit incorporant documentació (actualment arriba als 31.336 registres).

Amb la voluntat de donar a conèixer les seves col-leccions, progressivament molts centres patrimonials les difonen en els seus webs, tant mitjançant els catàlegs bibliogràfics com publicant-ne les digitalitzacions.

Des de mitjans de 2018, ja està en línia la Biblioteca de l'Arxiu Històric de la Ciutat de Barcelona després d'un procés d'informatització i recatalogació. Entre els fons, hi ha publicacions que van des del naixement de la impremta fins a l'actualitat, sovint ingressades com a donació i llegat. En l'àmbit de I'Institut de Cultura de Barcelona, la Unió Excursionista de Catalunya (UEC) -fins al 1987 Unió Excursionista de Catalunya de Sants - ja disposa d'una part del seu fons institucional digitalitzat anys després que en fes cessió a l'Arxiu Municipal de Barcelona. Fins ara només es podia consultar el seu catàleg a través del CCUC.

El 2018 també ha estrenat nou web l'Arxiu Diocesà, Arxiu Capitular de la Catedral, Biblioteca Diocesana del Seminari de Girona. Per una banda, les digitalitzacions fetes gràcies a la col-laboració d'Eduard i Alfons Martinell i Pere Trijueque es poden consultar in situ a través de la intranet institucional així com nova informació publicada al seu web. El 2019 la Biblioteca ha completat la catalogació de les seccions de música i tot el conjunt de documentació musical, tant dels dos arxius com de la biblioteca, i es troben disponibles per a la consulta.

Entre altres noves col-leccions a la xarxa en aquest període, no podem deixar de citar els dietaris de vuit biblioteques populars de la Mancomunitat als quals podeu accedir des del repositori Trencadís de la Diputació de Barcelona, o la digitalització del fons del fotògraf Oriol Maspons per part de l'arxiu del MNAC. Un recurs de tipus dietarístic ha estat el difós al web per l'Associació Memòria i Història de Manresa en col-laboració amb la Biblioteca Popular de Manresa, una de les primeres al país creades per la Mancomunitat. Entre la documentació i els fons antics, també hi ha el web del Dietari de la Biblioteca Popular de Manresa (1928-1939), que va ser digitalitzat per la Diputació de Barcelona.

L'Observatori de l'Ebre, en col-laboració amb l'Institut Cartogràfic i Geològic de Catalunya mitjançant un conveni, ha digitalitzat i difós a través de la Cartoteca Digital de Catalunya una selecció dels seus mapes més rellevants, entre els quals destaquen algunes litografies de gravadors catalans com Domènec Estruch i Jordan i Pau Alabern i Molas datats de l'any 1830 a 1834; mapes alemanys, italians, espanyols; mapes de guerra del segle xix i primers del xx, així com de la Primera Guerra Mundial.

L'octubre de 2018, l'Ateneu Barcelonès va inaugurar el projecte Veus de la

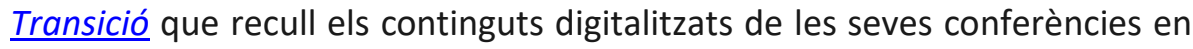
cintes magnetofòniques des dels anys setanta als noranta i que estan
Amb la voluntat de donar a conèixer les seves col•leccions, progressivament molts centres patrimonials les difonen en els seus webs, tant mitjançant els catàlegs bibliogràfics com publicant-ne les digitalitzacions 
disponibles al portal L'Arxiu de la Paraula. L'exposició virtual es feu en col-laboració amb la Diputació de Barcelona i l'Ajuntament de Barcelona. A més a més, s'han descrit i digitalitzat els fons personals Josep Maria Roca i Heras i Lluís Carreras Lastortras.

Amb vista a ampliar la seva accessibilitat, el portal de difusió de col·leccions digitalitzades del Museu Nacional de la Ciència i de la Tècnica de Catalunya (mNACTEC) s'ha migrat a Fotoweb i, des del 2018, està també disponible en francès. Pel que fa a la cerca per tipus de document, permet la cerca per «llibre antic».

La Biblioteca Digital del Patrimonio Iberoamericano (BDPI) es va inaugurar el setembre de 2018; les col-leccions digitalitzades de la Biblioteca de Catalunya hi estan representades, pel fet de formar part de la Biblioteca Digital Hispánica.

Com a novetats tècniques, l'Arxiu de Revistes Catalanes Antigues (ARCA) ha canviat a una nova plataforma, basada en DIGIBIS, amb noves prestacions més enfocades a l'experiència de l'usuari o personalització, i la Filmoteca de Catalunya ha millorat la consulta del seu repositori digital amb nous recursos, tant digitalitzats com nascuts digitals.

La Xarxa de Biblioteques Especialitzades de la Generalitat, en el marc dels nous projectes de futur, des del 2018 forma part d'un nou grup de treball anomenat PIGencat (Propietat Intel-lectual de la Generalitat) format tant per bibliotecaris com arxivers amb l'assessorament d'advocats. Les qüestions legals, tal com hem vist, són un tema crític a l'hora de publicar continguts, especialment en el cas dels fons patrimonials, i molt especialment quan parlem de reutilitzar-los.

Fruit de la col-laboració entre diferents tipus de centres i professionals, citem el projecte transversal iniciat l'any 2018 per l'Arxiu Municipal de la Palma de Cervelló, conjuntament amb la biblioteca municipal, per tal de dur a terme la recollida de material gràfic entre els veïns. Des de mitjans de 2019, es poden consultar les imatges al portal de la Diputació de Barcelona Imagina. En aquesta línia, s'ha inaugurat el projecte participatiu Memòria Visual Trinitat Vella, en el qual col-labora l'Associació per a la Recerca i Divulgació de la Memòria Històrica de Trinitat Vella, la Biblioteca Trinitat Vella - José Barbero, l'entitat Baja a la Plaza, l'Arxiu Fotogràfic de Barcelona i l'Observatori de la Vida Quotidiana.

\subsection{Bases de dades}

Les bases de dades consolidades del CRAI Biblioteca de Reserva de la Universitat de Barcelona continuen creixent. La base de dades Marques

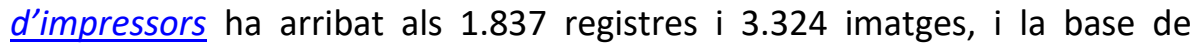
dades Antics posseïdors ha arribat als 1.474 registres. Aquest 2019, a més a més, el cronomapa de la base de dades Marques d'impressors s'ha
ARCA ha canviat a una nova plataforma, amb noves prestacions més enfocades a l'experiència de I'usuari

\section{La Filmoteca de Catalunya ha millorat la consulta del seu repositori digital amb nous recursos, tant digitalitzats com nascuts digitals}


optimitzat per tal de poder-se visualitzar sense problemes als navegadors Chrome, Mozilla i Explorer.

El portal SiDBRINT: memòria històrica Brigades Internacionals, un projecte liderat per la Biblioteca del Pavelló de la República de la UB, a finals de 2019 ha arribat a la xifra de 28.000 brigadistes registrats i més de dues mil fonts repertoriades. A més a més, el mes de març de 2019 va finalitzar la primera fase de renovació del web, que ha consistit en un canvi total del disseny de la pàgina i les seves funcionalitats.

La Biblioteca de la UdG ha seguit incorporant articles i revisant enllaços de Bertrana de Capçalera, la base de dades creada amb motiu de l'Any Bertrana i que recull tota la producció periodística, tant d'Aurora com de Prudenci Bertrana, que s'ha pogut localitzar fins al moment. Una altra actuació està relacionada amb les bases de dades de dedicatòries, que permeten reconstruir la xarxa de contactes dels protagonistes dels fons especials, i que han estat migrades a un nou sistema (SQL Server a MySQL) per millorar la interfície de consulta de l'usuari, així com l'entorn de treball. En l'àmbit de les biblioteques universitàries, informem de la nova pàgina web a través de la qual es poden consultar els fons especials de la Universitat de Vic, que estan disponibles des del mes d'abril de 2018.

Cada vegada són més les biblioteques que posen obertes al públic les seves col-leccions, com és el cas del centre de documentació del Museu d'Art Contemporani de Barcelona (MACBA) que, si bé es va inaugurar el 2017, fins ara no s'havia obert al públic. Té una part destinada als fons documentals amb fons personals, l'arxiu històric del Museu i les col-leccions documentals de l'arxiu i la biblioteca. El Museu de la Música també ha presentat el web del seu arxiu fotogràfic, un projecte de repositori i alhora portal per difondre les seves col-leccions especials. La Càtedra Màrius Torres, vinculada a la Universitat de Lleida (UdL), ha incorporat les digitalitzacions del Fons Manuel de Pedrolo del Castell de Concabella i del Fons d'Edicions 62 de la Biblioteca de Catalunya al seu Corpus Literari Digital, en el marc de la celebració del centenari del seu naixement.

El Centre de Documentació i Museu de les Arts Escèniques (MAE) també ha renovat els seus recursos digitals: concretament, la pàgina inicial $i$ el programari de l'Hemeroteca Digital, que ha permès no només agilitzar la feina sinó, a més a més, iniciar la catalogació de premsa retrospectiva a través de dossiers. El 2019 s'ha recuperat la base de dades Dramatúrgia Catalana Contemporània (DCC), de l'Institut del Teatre, amb el suport de la Societat General d'Autors i Editors i l'Associació d'Escriptors en Llengua Catalana, que recull informació detallada sobre obres dramàtiques escrites en català. A més a més, inclou una nova base de dades amb voluntat de ser un projecte de país: I'AAAEC, l'Arxiu Audiovisual de les Arts Escèniques de Catalunya.

Des de l'estiu de 2018, també podeu consultar a CALAIX la Fonoteca de Música Tradicional Catalana. I en l'àmbit del patrimoni industrial de Catalunya, està disponible des del 2019 un catàleg digital georeferenciat,
Cada vegada són més les biblioteques que posen obertes al públic les seves col-leccions: el MACBA, el Museu de la Música o el MAE, entre d'altres 
Patrimonilndustrial.cat, que recull casos d'estudi, entre els quals destaquem «El llegat bibliogràfic dels 150 elements del patrimoni industrial català» $i$ «Fons gràfic de fàbriques de Barcelona (s. XVIII-XX)».

La biblioteca universitària de I'Escola Tècnica Superior d'Arquitectura de Barcelona ha publicat també una guia temàtica amb motiu del centenari del naixement de Giancarlo de Carlo (1919-2005) el desembre de 2019.

Gràcies al Centre de Documentació Ramon Llull, hi ha disponible també un altre recurs en línia. Es tracta del Glossari general lul-lià creat a partir de les obres que se'n conserven. Dues altres bases de dades que s'han incorporat a la Biblioteca Digital de Catalunya són BaDeMar de la biblioteca de la Facultat de Nàutica i la Bibliografia de Geologia de la Península Ibèrica (BIGPI) del CRAI Biblioteca de Ciències de la Terra de la Universitat de Barcelona.

El catàleg col-lectiu de les biblioteques del CSIC, xarxa de la qual formen part algunes biblioteques de museus com ara del Museu de Ciències Naturals de Barcelona, va completar a principis de 2018 la migració al sistema de gestió ALMA i la interfície del seu catàleg d'autoritats ja torna a estar disponible per a la consulta. Des del 2019 aquest catàleg col-lectiu està integrat dins del catàleg WorldCat d'OCLC. Els fons i colleccions de l'Ateneu Barcelonès també hi estan integrades des de l'octubre de 2019.

La Cartoteca Digital de I'Institut Cartogràfic i Geològic de Catalunya presenta, en aquests dos anys, novetats: per una banda, el 2018 va començar a catalogar amb RDA, que permet la incorporació de les coordenades dels mapes a la descripció, i, per l'altra, s'ha dut a terme la digitalització de mapes analògics que s'han pogut associar a la fototeca digital.

\subsection{Projectes transversals i participatius}

El Catàleg Col-lectiu del Patrimoni Bibliogràfic Català (inscrit en un projecte d'abast estatal) ha crescut en membres aquests dos darrers anys, ja que s'hi han incorporat els fons bibliogràfics $\mathrm{i}$ de manuscrits dels monestirs benedictins de Sant Benet de Montserrat i de Sant Pere de les Puel-les.

Durant aquest període s'han iniciat projectes rellevants com els que comentem a continuació.

El juliol de 2019 es va estrenar Premsa digitalitzada, una nova eina col-laborativa d'abast nacional, impulsada per la Biblioteca de Catalunya, que comparteix recursos de biblioteques i arxius, públics i privats. Es tracta d'un inventari que inclou revistes i diaris catalans amb versions digitalitzades com a agregador de continguts.

Durant el bienni 2018 i 2019 el CRAI Biblioteca de Reserva de la Universitat de Barcelona ha participat a \#ColorOurCollections, una iniciativa anual endegada per The New York Academy of Medicine Library a través de la
La Cartoteca Digital, que va començar el 2018 a catalogar amb RDA, ha incorporat les coordenades dels mapes a la descripció

EI CRAI Biblioteca de Reserva de la UB ha participat a la iniciativa

\#ColorOurCollections que promou la participació dels usuaris acolorint imatges de les seves col·leccions

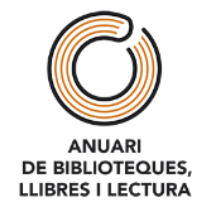


qual biblioteques, museus i altres institucions culturals comparteixen imatges de les seves col-leccions amb la voluntat que els usuaris i seguidors les acoloreixin i les publiquin novament a Twitter, Facebook, Instagram i Pinterest amb l'etiqueta \#ColorOurCollections. També hi ha col-laborat la biblioteca de la Universitat de Lleida.

Tal com destacàvem a l'ANUARI anterior, durant aquest període s'ha mantingut la participació de les biblioteques en projectes estatals i internacionals de llarga durada. Per exemple, el CRAI Biblioteca de Reserva de la Universitat de Barcelona ha continuat participant en el MEI, el CERL

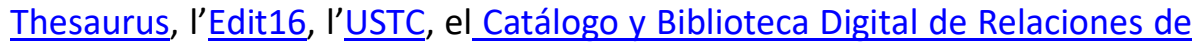
Sucesos (siglos XVI-XVIII) , el Catálogo Colectivo de Marcas de Fuego, així com amb el Gesamtkatalog der Wiegendrucke (GW).

Durant aquest bienni, el CRAI Biblioteca de Reserva ha augmentat la participació en projectes externs internacionals gràcies a la seva adhesió al Preserving the World's Rarest Books - amb el qual ha signat un acord per incloure el catàleg de fons antic de la UB en la detecció de les obres més rares del món-, al Footprints, al qual ha facilitat totes les edicions que estan en hebreu o que tenen "hebreu» com a matèria perquè s'incloguin en aquest recurs, i a The European Jesuits Libraries Provenance Project, al qual ha incorporat els registres bibliogràfics amb antic posseïdor jesuïta. Dins l'àmbit de l'Estat espanyol, a partir de 2018, la Biblioteca de Catalunya, la Biblioteca de Montserrat, el CRAI Biblioteca de Reserva i Toni Iglesias (UAB) estan col·laborant amb el projecte Incunables Españoles, liderat per Fermín de los Reyes. Algunes d'aquestes biblioteques també col·laboren indirectament amb el projecte Comedic (Catálogo de Obras Medievales en Castellano) en què incorporen els seus registres bibliogràfics a partir de la base de dades Philobiblion.

En la línia endegada anteriorment, el CRAI Biblioteca de Reserva de la Universitat de Barcelona ha continuat completant entrades a la Viquipèdia, aquest cop dels convents més representats a la seva col·lecció i que formen part de la seva base de dades Antics posseïdors. Unes altres iniciatives relatives a la Viquipèdia que s'han dut a terme, a més de les entrades fetes per les entitats culturals del país, són, en primer lloc, La Bonne - Centre de Cultura de Dones Francesca Bonnemaison, que, juntament amb el sindicat Sindillar i El Born CCM, centre especialitzat en memòria viva, van organitzar l'octubre de 2019 la trobada Wikidones i una ruta de memòria per Barcelona al voltant del procés de creació escènica amb perspectiva feminista i en el marc del BornLab. La Biblioteca de la Universitat de Girona ha completat les entrades a Viquipèdia per als seus diferents fons, i les ha relacionat amb les pàgines dels seus protagonistes. En segon Iloc, la participació catalana a través del Col-legi Oficial de BibliotecarisDocumentalistes de Catalunya a la Campanya \#1lib1ref 2019 i, com a tasca cultural de voluntariat ciutadà, en el marc també de les Jornades Europees del Patrimoni, comentem la Viquimarató de les biblioteques públiques del Vallès Oriental i Amical Wikimedia, que hi ha participat amb la càrrega de 21.666 imatges sobre el patrimoni local que referma també la implicació de
Durant aquest

període s'ha

mantingut la

participació de les

biblioteques en

projectes estatals i

internacionals de

llarga durada 
tot tipus de centres d'informació en la difusió del patrimoni a tots nivells.

El projecte Espais Escrits, en què participen diverses biblioteques catalanes amb fons literaris, ha remodelat el seu web per aconseguir una major usabilitat. Els fons de molts dels escriptors que hi estan representats estan conservats a la Biblioteca de Catalunya.

Durant el 2019, la Biblioteca de Catalunya ha incorporat la col-lecció Cartes Rebudes per Joan Maragall al projecte Transcriu-me, un projecte de crowdsourcing amb què la ciutadania contribueix a la transcripció del text de les imatges digitalitzades perquè siguin cercables i recuperables. El passat 31 de gener de 2018, el Consejo de Cooperación Bibliotecaria va reconèixer la Biblioteca per aquesta iniciativa amb el segell CCB.

L'Ateneu Barcelonès, emprenedor amb el projecte Almirall, continua la seva tasca de generació de continguts amb un projecte pilot anomenat AteneuLab: Socis Grans, Grans Històries pel qual fou guardonat en els Premis Ateneus 2018. Hi collaboren deu socis, a partir dels records i de la participació i està implementat amb la plataforma Collectic.

La xarxa de biblioteques i arxius del CSIC van començar el 2018 a arxivar tots els tuïts de l'usuari @bibliotecascsic.

\subsection{Xarxes socials}

La presència a xarxes socials durant aquest bienni s'ha consolidat i ampliat. Un bon exemple és el CRAI Biblioteca de Reserva, que en aquest període ha augmentat la seva presència a les xarxes. D'una banda, el juny de 2018 va estrenar canal a YouTube amb un doble objectiu: d'una banda, oferir un petit aparador amb vídeos de la UB relacionats amb el seu fons $i$, de l'altra, agrupar i facilitar l'accés a vídeos considerats interessants $i$ dels quals havien fet difusió prèviament a través del seu blog o Facebook. Una altra xarxa social a destacar on va decidir submergir-se el CRAI Biblioteca de Reserva a finals de 2018 va ser Instagram. L'èxit en aquest cas va ser immediat: en només un any s'ha assolit la xifra de més de sis-cents seguidors. Cal destacar que la posada en marxa d'aquesta xarxa social va ser fruit d'una col-laboració docent amb els estudiants de l'assignatura Laboratori de Projectes de Disseny Professional, dirigida pel professor Jesús del Hoyo Arjona, del grau de Disseny de la Facultat de Belles Arts de la Universitat de Barcelona. Els estudiants, que van dur a terme una pràctica de promoció de la nostra biblioteca basada en l'aprenentatge basat en projectes, van evidenciar la necessitat de promoure el fons a través d'aquest canal, molt més proper a la seva franja d'edat que no pas Facebook, com es feia només aleshores. Es tracta d'un bon exemple de com la col-laboració pot ajudar a obrir la mirada i ampliar perspectives.

La Universitat de Girona ha seguit amb la publicació dels vídeos promocionals dels seus fons especials a YouTube, amb la publicació el 2019 del vídeo de presentació del Fons Prudenci i Aurora Bertrana. També la

La presència $a$

xarxes socials durant aquest bienni s'ha consolidat i ampliat i cada vegada són més les biblioteques que obren canals per compartir les seves col/leccions a través de YouTube, Instagram, Flickr, Twitter o Facebook 
Universitat Autònoma de Barcelona ha publicat el 2019 el vídeo del Fons Carandell dins el seu canal YouTube, a la col-lecció Els Nostres Fons.

La Universitat de Lleida opta per Flickr, Instagram, Twitter i Facebook per a la difusió dels fons. El 2018 ha publicat els àlbums de fotos a Flickr corresponents als Fons Francesc Porta i Vilalta i el Fons Romà Sol - Carme Torres i a Facebook hi ha publicat la digitalització dels programes de les Festes Majors de Lleida, pertanyents al Fons Romà Sol. A Flickr i Instagram hi ha publicat una exposició virtual sobre el fons discogràfic COPE Lleida i Ràdio Girona - Cadena SER.

Per acabar, cal destacar que en alguns casos s'ha fet evident que la presència a xarxes sobre les quals no es té cap control pot acabar generant més d'una disfunció en la planificació de les iniciatives plantejades inicialment sobre el paper. Aquest ha estat el cas, per exemple, de l'aventura que el CRAI Biblioteca de Reserva va iniciar a Pinterest amb els seus taulers de "Papers decorats», on de sobte totes les imatges penjades van perdre l'enllaç al registre bibliogràfic al qual estaven vinculades. Això va motivar-los a aturar la participació en aquesta xarxa social i endegar una nova iniciativa a la seva pàgina web que poguessin controlar, la col-lecció especial Papers Decorats.

Aquests darrers anys moltes biblioteques han augmentat la presència a les xarxes socials com també ampliat la seva cobertura. La Biblioteca de Catalunya, per exemple, ha creat noves seccions per difondre els seus fons patrimonials sota les etiquetes \#TemaDelMes, \#DijousDePoesia i \#DivendresHistòria. Els dimecres també els dediquen a efemèrides de personatges, publicacions, aniversaris o esdeveniments assenyalats. El seu web, com a novetat, dona accés també a un recull de recursos organitzats i etiquetat amb Tagpacker. El Centre de Lectura de Reus, per la seva banda, més enllà d'estar present a Facebook, Twitter i Vimeo, va decidir aquest 2019 que el seu canal d'Instagram ja no estaria orientat únicament al públic de la biblioteca infantil sinó que també seria emprat per a la difusió dels seus fons patrimonials.

La Biblioteca Pública de Girona Carles Rahola, a part de tenir a nivell general, presència a Facebook, Instagram, Twitter, Spotify i un blog, ha publicat el 2019 el vídeo Dinamització del Fons Patrimonial a YouTube, que s'emmarca dins el projecte de difusió i socialització del patrimoni anomenat CODEX.

Pel que fa a les biblioteques de museus, la majoria no donen accés als comptes de les xarxes socials a través dels seus webs de manera directa sinó des del web dels museus respectius. D'aquest fet es dedueix que la majoria de biblioteques no disposen d'un perfil propi; una excepció és el Centre de Documentació del Museu de Ciències Naturals de Barcelona que l'agost de 2019 es va afegir a Twitter amb el compte@MCNBbiblioteca, diferenciat del Museu: @museuciencies.

\section{En alguns casos s'ha fet evident que la presència a xarxes sobre les quals no es té cap control pot acabar generant més d'una disfunció en la planificació de les iniciatives plantejada inicialment}


L'Ateneu Barcelonès ha continuat utilitzant les xarxes socials en el marc del projecte @ateneu Lab: Twitter, Facebook, YouTube i Flickr i, des del 2019, participa del projecte Fluidr, a partir de I'API de Flickr. Aquesta nova aplicació, que allotja imatges -i ofereix la possibilitat d'incorporar també vídeos-, permet usar els marcadors de "M'agrada», afegir a preferits, categoritzar de manera jeràrquica les etiquetes i triar diferents opcions de visualització. Implementa també opcions de cerca avançada (escollint el lloc on es vol que apareguin els termes introduïts: tipus de document, etiquetes, text, preferits o a tot arreu), la navegació a través d'un núvol d'etiquetes i afavoreix la reutilització dels objectes digitals emprant el codi i escollint diferents paràmetres tècnics, per poder integrar-los en altres webs. Fins i tot, fent clic a l'opció Surprise, el sistema genera galeries d'imatges aleatòriament. Es requereix identificació al portal per poder interactuar-hi.

\subsection{Homenatges}

Aquest bienni també ha destacat per alguns aniversaris i celebracions. A finals de 2018 l'exposició "Paradisini, marques tipogràfiques al jardí» va servir per commemorar els vint anys de l'inici de la base de dades Marques d'impressors del CRAI Biblioteca de Reserva. També a finals de 2018 la Universitat de Girona i la Biblioteca de Catalunya, amb la participació de la Facultat de Documentació de la UB, van organitzar conjuntament un acte d'homenatge a la figura d'Antoni Palau i Dulcet i alhora d'agraïment als seus successors per la donació a la UdG de les fitxes que es van utilitzar per publicar el Manual del Librero Hispanoamericano, referent indiscutible dins el món de les biblioteques patrimonials. Un any després, a finals de 2019, l'exposició "La vida privada dels llibres del CRAI Biblioteca de Reservą" va servir per celebrar els deu anys dels Antics Posseïdors, el recurs que va donar a conèixer les persones $\mathrm{i}$ les institucions que van ser propietàries dels llibres custodiats al CRAI Biblioteca de Reserva. Aquest 2019 també s'ha commemorat el cinquantè aniversari del Col-legi d'Arquitectes de Catalunya amb una exposició sobre la història arquitectònica del país, i s'ha fet la cloenda del centenari de les primeres biblioteques populars creades per la Mancomunitat de Catalunya, que custodien fons patrimonials considerables. La premsa també s'ha fet ressò del 124è aniversari de la Biblioteca Pública Arús, que el març de 2019 també ha recuperat una sèrie de llibres dels segles xviii i xix sostrets durant la postguerra. El juny de 2018, la Biblioteca de Catalunya va poder recuperar també la còpia d'una carta de Cristòfor Colom del 1493 que narrava les seves experiències a Amèrica i que havia estat sostreta feia més d'una dècada.

\section{Aquest bienni també ha destacat per alguns aniversaris i celebracions}

\section{Es constata la importància i la consolidació de les humanitats digitals a casa nostra}

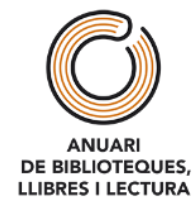




\section{NOUS ROLS PER A LES BIBLIOTEQUES PATRIMONIALS I ELS SEUS PROFESSIONALS}

\subsection{Humanitats digitals}

Si a l'ANUARI anterior vam definir el bienni 2016-2017 com el de la introducció definitiva de les humanitats digitals a casa nostra, el bienni 2018-2019 ha estat el de la constatació de la importància d'aquesta nova forma d'aproximar-nos a les humanitats i l'escenificació d'aquest nou rol, com posa de relleu la celebració al CSUC, el 15 de març de 2018, del curs "Humanitats digitals i biblioteques», que va impartir Núria Bel, professora de la Universitat Pompeu Fabra; Mariona Coll, d'Inbenta, i Sílvia Arano, de la Fundació per a la Promoció de l'Autoocupació de Catalunya. Hi van participar un total de trenta assistents de dotze institucions diferents. Podríem afirmar que la culminació d'aquest augment de protagonisme de les humanitats digitals a casa nostra i l'interès creixent dins del sector de les biblioteques per les humanitats digitals ha estat la creació del Grup de Treball de Bibliotecaris d'Humanitats Digitals (digital humanities, DH) de les universitats membres del CSUC i de la Biblioteca de Catalunya. Els objectius principals d'aquest grup són: copsar quin tipus de recerca s'està fent en l'àmbit de les humanitats digitals per tal d'identificar com hi poden contribuir les biblioteques i centres de recursos i millorar la formació dels professionals per encarar els nous reptes que plantegen les humanitats digitals.

Estretament lligat amb aquest tema cal destacar també la posada en marxa, el setembre de 2019, del màster d'Humanitats Digitals, sota el paraigües de les facultats d'Informació i Mitjans Audiovisuals, de Geografia i Història, de Filosofia i de Filologia i Comunicació de la Universitat de Barcelona, un màster en què aprofundirem més endavant.

Des de 2018, la UAB ofereix un curs MOOC sobre Humanitats Digitals a la plataforma Coursera. El curs està impartit per professorat de la UAB amb la col-laboració de personal del CRAI de la UAB i ofereix una panoràmica introductòria sobre els usos i possibilitats de les humanitats digitals en l'actualitat. Els responsables del MOOC formen part de la Xarxa d'Humanitats Digitals de la UAB, que també va organitzar les I Jornades d'Humanitats Digitals que van tenir lloc l'abril de 2018 i on va participar personal de les biblioteques de la UAB exposant alguns dels projectes en què estaven colllaborant en aquell moment.

\subsection{Les biblioteques com a generadors de continguts}

El setembre de 2019, es posa en marxa el màster

d'Humanitats

Digitals, sota el

paraigües de les

facultats

d'Informació i

Mitjans

Audiovisuals, de

Geografia i Història, de Filosofia i de

Filologia i

Comunicació de la

Universitat de

Barcelona 
Es consolida la tendència que blogs determinats estretament lligats al món patrimonial -CRAI Biblioteca de Reserva i CRAI Pavelló de la República de la Universitat de Barcelona o el blog de la Biblioteca de Catalunya- cada cop apostin més per generar continguts propis i especialitzats de tipus tècnic, sobre els propis fons o bé sobre esdeveniments $i$ activitats del sector. La tendència, que va iniciar el blog de la Biblioteca de Catalunya signant les entrades al seu blog, l'ha seguit ara el CRAI Biblioteca de Reserva de la Universitat de Barcelona, on tradicionalment l'opció de signar les entrades era restringida a les aportacions de col-laboradors externs. A partir de l'experiència del blog de la Biblioteca de Catalunya i d'altres blogs del sector es va considerar que aquesta pràctica era una bona via per augmentar la visibilitat i la reputació del seu personal, tant a nivell individual com institucional.

D'altra banda, tenint en compte la institució de la qual forma part i amb la voluntat d'arribar a un públic més ampli -no només als especialistes en fons antic-, el CRAI Biblioteca de Reserva també ha optat per emprar el blog com a pilar de difusió de continguts generats pels propis estudiants, és a dir, com una plataforma per tal de visualitzar part del suport a la docència que s'ofereix, així com de difusió de recerques que, molt probablement, quedarien en un calaix o dipositades al Dipòsit Digital de la UB i no se'n faria més ressò. Aquesta ha estat una via de difusió dels treballs dFaceha tingut una molt bona acollida, ja que generalment l'alumnat no considera que els seus treballs puguin tenir més recorregut $o$ atenció que el merament acadèmic; constatar l'interès del personal de la biblioteca els ha motivat a aprofitar l'oportunitat que la Biblioteca els brinda de publicar en el seu blog.

Cal destacar també algunes iniciatives que no sorgeixen de l'àmbit públic però que també tenen una rellevància especial. Ens referim a un projecte col-laboratiu ja consolidat $i$ al qual vam fer esment a l'ANUARI anterior Castell Interior - centrat en l'estudi, difusió i intercanvi d'informació sobre la història del Carmel descalç a Catalunya des de 1586 fins a l'actualitat, i que aquest darrer bienni ha apostat per potenciar la creació de nous recursos per a la investigació. El web Castell Interior és obra d'un equip constituït per la filòloga Maria Toldrà (administradora del web i responsable de continguts) i la historiadora Mercè Gras, arxivera de l'Arxiu dels Carmelites Descalços de Catalunya i Balears (responsable dels continguts). Els continguts del blog i els projectes paral-lels inclouen les aportacions i la col-laboració d'investigadors de diferents especialitats (filologia, història, història de l'art, etc.), fet que l'ha acabat definint com un generador de continguts molt especialitzats i d'alt nivell, inclosos sobre llibre antic, on sovint es fa referència a fons patrimonials.

El centre de documentació del Museu de la Ciència i la Tècnica de Catalunya, de Terrassa, ha estrenat també un apartat de recursos dins d'un nou blog temàtic, en la línia de publicació amb continguts especialitzats, com a nou espai virtual obert dedicat a la història de les tecnologies de la informació a Catalunya: Del telègraf a Internet. Hi aporta bibliografia i articles relacionats. També ha incorporat al seu portal dues noves guies
Es consolida la tendència que blogs determinats

estretament lligats al món patrimonial cada cop apostin més per generar continguts propis i especialitzats de tipus tècnic, sobre els propis fons o bé sobre esdeveniments i activitats del sector 
temàtiques amb la recomanació de documents al voltant d'uns temes específics:_"Guia temàtica sobre pobles obrers i ciutats fàbrica» i "Guia temàtica sobre històries al voltant del tèxtil i la moda" (2018).

\section{FORMACIÓ}

En aquest bienni es continuen impartint les titulacions i ensenyaments que es van esmentar a l'article anterior, i es consolida així el màster de Biblioteques i Col-leccions Patrimonials, que acostuma a moure's en una forquilla d'entre vint i trenta alumnes. Durant els biennis 2018-2019 i 20192020, el perfil d'alumnes d'Humanitats matriculats en aquest màster s'ha incrementant en relació amb el d'estudiants de Documentació, fet que ha comportat dissenyar alguns canvis en les assignatures de complements de formació previstos de cara al nou bienni 2020-2022. En general, s'adrecen a aquest màster alumnes interessats en el patrimoni cultural que inicien estudis de Biblioteconomia com a nova via professionalitzadora, a banda dels professionals de la informació que cerquen una especialització en aquest camp. Com ja acostuma a ser habitual, biblioteques patrimonials com el CRAI Biblioteca de Reserva, la Biblioteca de la Universitat de Girona o la Biblioteca de I'ICAB han tingut alumnes d'aquest màster en pràctiques (tant de tipus curriculars com no curriculars) i hi han collaborat oferint sessions als seus alumnes. Paral-lelament, tres alumnes d'aquesta edició han tingut l'oportunitat de cursar les pràctiques en centres patrimonials estrangers: la Biblioteca de I'Instituto Cervantes d'Hamburg, la Glasgow Women's Library i la Bodleian Library de la University of Oxford.

Com s'ha exposat anteriorment, cal destacar també la irrupció d'una nova titulació: el màster d'Humanitats Digitals, una iniciativa de la Universitat de Barcelona fruit de la collaboració de les facultats d'Informació i Mitjans Audiovisuals, Geografia i Història, Filosofia, i Filologia i Comunicació. En aquesta primera edició del màster d'Humanitats Digitals s'hi han matriculat un total de disset alumnes, majoritàriament provinents dels àmbits de la història, informació i documentació, i llengües i literatures modernes, tot i que també hi trobem representats estudiants provinents dels àmbits de la comunicació audiovisual; ciències de l'activitat física i l'esport; filosofia; humanitats; lingüística, i sociologia.

La Universitat Politècnica de Catalunya ha establert un conveni amb el grau de Conservació i Restauració de la Facultat de Belles Arts de la Universitat de Barcelona per endegar un programa de beques de cooperació educativa amb l'objectiu que es puguin dur a terme els tractaments de neteja, conservació i emmagatzematge correcte del seu fons patrimonial.

Continua impartint-se el postgrau El Llibre Antic: Història i Anàlisi del Patrimoni Bibliogràfic, organitzat per la Facultat d'Informació i de Mitjans Audiovisuals de la Universitat de Barcelona, que al llarg d'aquest bienni ha mantingut la seva aposta per les experiències professionalitzadores i ha organitzat diverses visites i tallers: consulta de llibres impresos dels segles xv a xix amb el professor Jesús Gascón al CRAI UB, Biblioteca de Reserva;

\section{Es consolida el màster de Biblioteques i Col·leccions} Patrimonials amb el que han col-laborat diverses

Biblioteques patrimonials, impartint sessions especifiques i/o acollint alumnes en pràctiques 
Laura Moré, "La gestió dels fons especials a la Biblioteca de la UdG»; CRAI Biblioteca Ciutadella de la Universitat Pompeu Fabra, a càrrec d'Imma Muxella; Arxiu Històric de la Ciutat de Barcelona; Isabel de Colmenares, «Experiencias en bibliotecas patrimoniales eclesiásticas»; Josep Vives i Gràcia, "Ėtica bibliotecària en temps de crisi»; CRAI UB. Biblioteca de Reserva, a càrrec de Marina Ruiz; Biblioteca de Catalunya - Museu del Llibre Marès, a càrrec de Marga Losantos i a la Biblioteca Museu Víctor Balaguer de Vilanova, amb una mostra de fons privats i materials efímers.

El personal especialitzat que treballa en biblioteques també ha participat en classes de formació d'estudis reglats com és el cas d'Anna Gudayol que ha impartit el curs "Lectura de manuscrits i textos (món antic i edat mitjana)» en el marc del màster en Història i Patrimoni Cultural: Història de l'Església, en conveni amb la Universitat Ramon Llull - Facultat de Filosofia, celebrat del 12 de febrer al 4 de juny de 2019. També va participar, en qualitat de membre del comitè assessor, en el $\mathrm{V}$ simposi internacional organitzat pel grup EMAC Judici i Justícia: Art Sacre Profà Medieval i Modern (Universitat de Barcelona, segon semestre del curs 2018-2019). Isabel de Colmenares va impartir la sessió de formació "Cómo hallar el "código de identidad" en un impreso antiguo" a l'Escola Superior d'Arxivística i Gestió de Documents el gener de 2019. També des de la UAB es va fer una xerrada sobre el fons del Liceu als alumnes de l'assignatura Gestió Cultural (II) Patrimoni del grau de Musicologia el març de 2019. En el marc de la formació a distància citem la conferència dels historiadors Xavier Cazeneuve i Albert Cubeles «Història de Barcelona a través de la cartografia i la fotografia», un curs de vuit hores organitzat per la UNED Barcelona durant el mes de març de 2018.

Més enllà de la formació reglada destaquem també l'oferta de cursos especialitzats vinculats als fons i objectius dels centres patrimonials, com ara:

- Gestió de fotografies en centres culturals: drets d'autor i imatge. Barcelona, COBDC, 27 de febrer de 2018.

- El llibre antic: història i anàlisi del patrimoni bibliogràfic. Barcelona, Facultat de Biblioteconomia i Documentació, febrer-juny de 2018.

- Taller de restauració d'enquadernacions americanes. Girona, Universitat de Girona. Aula Cartoteca, 16 d'abril de 2018.

- Iniciació a la restauració de documents. Barcelona, COBDC, 8 d'octubre de 2018.

- Protecció de dades per a bibliotecaris. Barcelona, COBDC, 31 d'octubre de 2019.

- Gestió de fons i col-leccions de fotografia. Barcelona, COBDC, del 16 d'octubre al 13 de novembre de 2019.

\section{Més enllà de la formació reglada destaca, durant aquest bienni, l'oferta de cursos especialitzats vinculats als fons $i$ objectius dels centres patrimonials i la intensificació dels intercanvis professionals d'experiències}


- Catalogació i format RDA: el nou estàndard. Mòdul de monografies antigues. Barcelona, COBDC, del 21 de novembre al 5 de desembre de 2019.

Durant el període 2018-2019 també ha pres una rellevància especial l'interès per potenciar els intercanvis professionals d'experiències. El juliol de 2019 el CSUC va organitzar la primera edició del programa d'intercanvis entre biblioteques universitàries amb l'objectiu de compartir coneixement i informació. D'entre tota l'oferta de visites, el CRAI Biblioteca de Reserva i el CRAI Biblioteca del Pavelló de la República de la UB, la Universitat Autònoma de Barcelona, la Universitat de Girona i la Biblioteca de Catalunya van oferir visites relacionades amb els seus fons patrimonials. Per la seva banda, durant aquest bienni el CRAI Biblioteca de Reserva de la Universitat de Barcelona va decidir impulsar les estades internacionals de professionals a la seva biblioteca, tant vinculades al programa Erasmus+ com a través d'iniciatives independents que no quedaven adscrites a aquest programa d'intercanvi internacional. El resultat de l'experiència ha estat la visita de deu alumnes Erasmus+ i quatre estades de personal estranger amb una valoració molt positiva per part de totes les parts, ja que es tracta de visitants amb perfils molt específicament vinculats al fons antic, fet pel qual es van optimitzar molt les estades i el guany de les experiències compartides va ser recíproc.

\section{RECERCA}

\subsection{Treballs i tesis}

Durant aquest bienni s'han defensat les tesis doctorals següents:

- Agustí, Lluís (2018). L'edició espanyola a l'exili de Mèxic: 1936-1956. Inventari i propostes de significat. Tesi doctoral dirigida per Mònica Baró i Teresa Férriz Roure. Universitat de Barcelona. <https://www.tdx.cat/handle/10803/667483>.

- Cruz Trujillo, Marta (2018). El manuscrito 981 de la Abadía de Montserrat: edición y estudio. Tesi doctoral dirigida per María José Muñoz Jiménez i Patricia Cañizares Ferriz. Universidad Complutense de Madrid. <https://eprints.ucm.es/49356/1/T40254.pdf>.

- Ortega, Marta (2018). Eulàlia Ferrer, viuda de Brusi: paradigma de la capacidad de obrar de las mujeres en la edición y librería barcelonesa del siglo xix. Tesi doctoral dirigida per Josep Capdeferro i Pedro Rueda. Universitat Pompeu Fabra. <https://www.tesisenred.net/handle/10803/664889>.
Després de dues dècades digitalitzant per preservar $i$ difondre el patrimoni que custodien, les biblioteques han de fer un salt endavant i apostar per la reutilització del patrimoni digital 
- Ruiz Fargas, Marina (2019). La biblioteca del Convent de Santa Caterina de Barcelona sota el mecenatge de fra Tomàs Ripoll, 1699-1747. Tesi doctoral dirigida per Pedro Rueda. Universitat de Barcelona. $<$ https://tdx.cat/handle/10803/669226>.

- Botanch, Eduard. Marques tipogràfiques d'àmbit català (segles xv-xvii). Repertori i estudi. Tesi doctoral. Universitat de Barcelona. Tot i haver-se presentat el curs 2015-2016, en fem una menció especial ja que el 19 d'abril de 2018 va rebre el premi extraordinari del doctorat.

En aquest període s'han presentat nombrosos TFG i TFM relacionats amb fons patrimonials $\mathrm{i}$ que han tingut com a objecte fons dipositats al CRAI Biblioteca de Reserva i el CRAI Biblioteca del Pavelló de la República de la Universitat de Barcelona, la Biblioteca de Catalunya, I'Institut d'Estudis Fotogràfics de Catalunya, la Cartoteca de I'Institut Cartogràfic i Geològic de Catalunya o la Biblioteca del Museu de Ciències Naturals de Barcelona, entre d'altres. La majoria de TFM han estat defensats dins el marc del màster de Biblioteques i Col-leccions Patrimonials el curs 2017-2018, en la convocatòria de juliol, i el curs 2018-2019.

Més enllà del màster de Biblioteques i Col-leccions Patrimonials, cal destacar especialment el TFM defensat per Àngels Rius i Bou - responsable de la Biblioteca del Monestir de Montserrat- i elaborat en el marc del màster en Gestión de la Documentación, Bibliotecas y Archivos de la Facultad de Ciencias de la Documentación (Universidad Complutense de Madrid) el 2018 Tipobibliografía de la imprenta del Monasterio de Montserrat: 1499-1524, dirigit per Fermín de los Reyes Gómez.

\subsection{Congressos, seminaris i reunions específiques}

L'organització de congressos, seminaris i altres tipus de reunions professionals específiques és un bon baròmetre per mesurar el dinamisme de la nostra professió. Durant aquest bienni, cites ja consolidades com la $\underline{\mathrm{V}}$ Jornada sobre Biblioteques Patrimonials de l'Ateneu Barcelonès o la $\underline{\mathrm{V}}$ Trobada de Fotografia a Museus, Arxius i Biblioteques, celebrada al Museu Marítim de Barcelona, han compartit protagonisme amb noves iniciatives com les I Jornades d'Humanitats Digitals de la Universitat Autònoma de Barcelona o les $\underline{1 \text { es Jornades sobre el Patrimoni Sonor i Audiovisual. }}$

Cal destacar també la segona edició de determinades iniciatives, com la segona trobada professional de biblioteques públiques i biblioteca universitària de l'àmbit gironí, Els Fons Patrimonials i Arxivístics, organitzada per les Biblioteques de la Diputació de Girona, Biblioteques de Girona i la Biblioteca de la Universitat de Girona o, quant a l'Estat espanyol però amb clara participació catalana, les II Jornadas de Patrimonio Bibliográfico Organitzades per REBIUN. La repetició d'iniciatives endegades el bienni anterior és una bona mostra de la solidesa del sector i que les propostes tenen bona acollida i voluntat de continuïtat.
L'organització de congressos, seminaris i altres tipus de reunions professionals específiques és un bon baròmetre per mesurar el dinamisme del sector $i$, en aquest sentit, l'activitat del bienni evidencia la seva solidesa 
Per acabar, celebrem iniciatives puntuals, com la taula rodona «El patrimoni bibliogràfic, a debat" - organitzada pel grup de recerca EXEMPLAR-, que han tingut una bona acollida i han esdevingut un punt de trobada i de diàleg per als professionals del sector.

Més enllà d'aquesta primera aproximació a les tendències més rellevants, trobareu una relació de tots els congressos, seminaris $\mathrm{i}$ reunions específiques organitzats al llarg d'aquest bienni a l'annex A. A l'annex C hem recollit les participacions dels professionals en aquests congressos $\mathrm{i}$ altres publicacions d'aquest bienni.

\section{EXPOSICIONS I DIFUSIÓ DEL PATRIMONI}

Enguany hem optat per llistar les exposicions i les activitats de difusió més rellevants d'aquest bienni a l'annex $B$. Tot $i$ això, volem apuntar en el cos de l'article algunes tendències que hem observat pel que fa a les estratègies de difusió del patrimoni. Alguns centres han apostat per organitzar de manera periòdica petites mostres als seus espais. Aquest seria el cas de la Biblioteca Museu Víctor Balaguer i la seva iniciativa La Vitrina, on mensualment exhibeix llibres i documents de diferents temàtiques amb l'objectiu de fer més visibles els seus fons amb monogràfics com «Llibres dedicats» o «Toldrà i Clausells, manuscrits i fotografies sobre l'amistat entre Eduard Toldrà i Manuel Clausells». Unes altres institucions, com l'Ateneu Enciclopèdic Popular, aposten per allargar la vigència de les exposicions oferint els materials expositius de "L'Any de la Canadenca, de la vaga al locaut», una exposició itinerant que van endegar el 2019. També cal destacar la posada en marxa d'exposicions virtuals, com «Premsa clandestina catalana» que la Universitat Autònoma de Bellaterra va estrenar l'11 de desembre de 2019, o la pàgina Exposicions virtuals del CRAI Biblioteca de Reserva de la Universitat de Barcelona, on es poden consultar les versions virtuals de totes les exposicions físiques que organitzen.

Més enllà de les exposicions organitzades per les mateixes biblioteques patrimonials, cal destacar la participació en exposicions externes amb la cessió de fons, com seria el cas del CRAI Biblioteca de Reserva de la Universitat de Barcelona a l'exposició "Barcelona, capital mediterrània", que va tenir lloc al Saló del Tinell del Museu d'Història de Barcelona entre el 29 de març i el 29 de setembre de 2019. Una posició destacada té novament la Biblioteca del Pavelló de la República de la Universitat de Barcelona, que al llarg del bienni 2018-2019 ha colllaborat en més d'una quinzena de programes de televisió, projectes audiovisuals i recursos web, així com amb gairebé una cinquantena d'exposicions i espais per a la recuperació de la memòria.

La Biblioteca de la UdG ha cedit fons per a nombroses exposicions, com ara «Kosmos Panikkar», celebrada al Palau Robert entre l'11 d'octubre de 2018
Algunes de les

tendències que

s'observen pel que

fa a les estratègies

de difusió del

patrimoni és

l'aposta que alguns

centres han fet per

organitzar de

manera periòdica

petites mostres als

seus espais o per

participar en

exposicions externes

amb la cessió de

fons 
i el 3 de febrer de 2019. També ha organitzat diverses mostres presencials, totes a la seva biblioteca del Campus del Barri Vell, d'entre les quals destaquen: una exposició amb motiu de l'acte de recepció del Fons Joan Ferraté, "La geografia dels fons especials de la Biblioteca» $\mathrm{i}$ «Mèxic i l'exili dels mestres de la República: els germans Bargés Barba i el Grupo Escolar Cervantes de Córdoba, Veracruz».

A les biblioteques de la UAB s'han organitzat el 2018 un total de quarantauna exposicions i mostres per contribuir a la difusió dels seus fons bibliogràfics. Algunes es poden consultar en línia al seu dipòsit digital.

La Biblioteca Pública de Girona Carles Rahola organitza nombroses activitats al voltant dels seus fons patrimonials, com són les visites per a diferents col-lectius (escolars, adults, famílies i professionals), tallers familiars de Món del Llibre (exlibris, escriptura antiga, caplletres) o el programa de voluntariat gràcies al qual es duen a terme tasques d'inventari i conservació preventiva del fons documental que d'una altra manera seria impossible de portar a terme. També ha seguit amb les seves exposicions que, sota el títol de $\underline{\text { La Perla }}$, contribueixen a acostar el patrimoni a la ciutadania. Finalment, el 2019 han museïtzat espais de la seva biblioteca amb tres exposicions permanents: "Reviu Rahola», a la sala de la col-lecció local, amb plafons i vitrines, centrats en la figura del periodista i escriptor que dona nom a la Biblioteca; al vestíbul hi han disposat diversos objectes que relliguen l'edifici actual amb l'antic (l'antic catàleg de fitxes, làmpada i màquina d'escriure), acompanyats d'un vinil amb un text d'Enric Mirambell, antic director, i, finalment, a l'espai Món Llibre, una exposició dedicada al fons patrimonial i que s'acompanya d'un moble d'impremta antic cedit per la Fundació Masó de Girona.

Dins l'àmbit de la difusió del patrimoni, una altra de les estratègies són les visites als fons patrimonials. El novembre de 2019 la Universitat de Girona ha participat en el projecte Lectures en Ruta amb una visita al Fons Prudenci i Aurora Bertrana. Lectures en Ruta és un programa d'immersió literària per a joves entre divuit $i$ vint-i-cinc anys amb l'objectiu de promoure l'intercanvi i la convivència al voltant de l'experiència literària, mitjançant visites a autors, editors i biblioteques d'arreu del país. Es tracta d'una iniciativa de l'empresa Tramoia Produccions Culturals amb la col-laboració del Servei de Biblioteques de la Direcció General de Cooperació Cultural i la Institució de les Lletres Catalanes. En la mateixa línia, les visites guiades a l'edifici històric de la Universitat de Barcelona inclouen també una visita al fons del CRAI Biblioteca de Reserva de la UB. Aquest bienni s'han dut a terme vuitanta-vuit visites de Protocol, amb un total de 996 assistents. Atesa la bona acollida que han tingut fins ara, durant aquest període s'ha optat per oferir visites al fons antic per als alumnes de la Universitat de l'Experiència de la Universitat de Barcelona, que estan tenint un èxit rellevant entre aquest col-lectiu concret.

Amb la voluntat d'afavorir la difusió del fons i l'ús de fons patrimonials amb finalitats docents, el CRAI Biblioteca de Reserva va decidir ampliar la seva oferta formativa el 2017 oferint el que ells anomenen sessions metodo-
Dins l'àmbit de la difusió del patrimoni, una altra de les estratègies que es manté són les visites als fons patrimonials 
lògiques, és a dir, sessions impartides pels bibliotecaris de fons antic que combinen el treball amb les fonts $\mathrm{i}$ la instrucció en competències informacionals amb aquest tipus de material tan particular. Al llarg del bienni 2018-2019 aquest nou tipus de sessió s'ha consolidat, i ha passat de setze sessions (i 248 assistents el 2018) a vint-i-dues sessions (i 480 assistents) el 2019.

Al marge de les visites que cadascuna de les biblioteques organitzen periòdicament, també se n'organitzen per a collectius diversos, com la visita Centre de Lectura de Reus (24 de març de 2018), una visita a la biblioteca patrimonial més antiga de Catalunya en el marc de les sortides de la sèrie Quedem? organitzades per Òmnium Cultural.

\section{BIBLIOGRAFIA}

Anglada, Lluís (2019). "LIBERant el canvi: informes I activitat de LIBER respecte a ciència oberta, dades FAIR i humanitats digitals». Blok de BiD, 2 d'octubre. $\quad<$ http://www.ub.edu/blokdebid/ca/content/liberant-el-canviinformes-i-activitats-de-liber-respecte-ciencia-oberta-dades-fair-i>.

Anglada, Lluís (2019). "Muchos cambios y muchas certezas para las bibliotecas de investigación, especializadas y centros de documentación». El Profesional de la Información, vol. 28, núm. 1 (enero-febrero). $<$ http://www.elprofesionaldelainformacion.com/contenidos/2019/ene/01 obs.pdf>.

Balada, Francesc; Barenblit, Ferran; Serra, Eugènia (2017). «La cooperació entre biblioteques, arxius i museus en la conservació, la preservació i la difusió del patrimoni a Catalunya». Item: Revista de biblioteconomia $i$ documentació, núm. 62, p. 113-123.

<https://www.raco.cat/index.php/Item/article/view/327919>.

Balagué, Núria (2020). "A cada tipologia d'universitat, la seva biblioteca». Blok de BiD, 29 de gener. <http://www.ub.edu/blokdebid/ca/content/cadatipologia-duniversitat-la-seva-biblioteca>.

"La Biblioteca Arús de Barcelona recupera llibres centenaris sostrets a la postguerra» (2019). El Nacional.cat, 3 de març.

$<$ https://www.elnacional.cat/ca/societat/biblioteca-arus-barcelonarecupera-llibres-centenaris-sostrets-postguerra 360726 102.html $>$.

Díaz Mota, Albert; Folia, Marc (2018). «Biblioteca i arxiu en un context museístic. Experiències LAM institucionals en el Museu del Disseny de Barcelona». 15es Jornades Catalanes d'Informació i Documentació. Barcelona, 10 i 11 de maig de 2018.

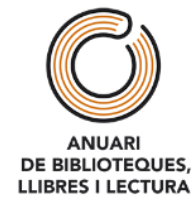


$<$ https://ajuntament.barcelona.cat/museudeldisseny/sites/default/files/pu blication article/exp36.pdf>.

European Commission. Directorate-General for Communications Networks, Content and Technology (2018). Implementation of Commission Recommendation on the digitisation and online accessibility of cultural material and digital preservation: consolidated progress report 2015-2017. Luxemburg: European Comission. <https://ec.europa.eu/digital-singlemarket/en/news/european-commission-report-cultural-heritage-

digitisation-online-accessibility-and-digital>.

Fenoll, Carme; Hinojo, Àlex (2017). "Cinc anys de Bibliowikis (2012-2017): I'Open GLAM pren força a les biblioteques catalanes». Item: Revista de biblioteconomia i documentació, núm. 62, p. 35-44.

<https://raco.cat/index.php/Item/article/view/327905/418425>.

Generalitat de Catalunya. Departament de Cultura (2018). Pla de Govern de la Generalitat de Catalunya (2018-21): biblioteques, l'Agenda 2030, ciberseguretat, Pla de Cultura Digital.

$<$ http://www.cobdc.net/document/noticies/pla-govern-generalitatcatalunya-2018-21-biblioteques-lagenda-2030-ciberseguretat-pla-culturadigital/>.

Harvell, Jane; Ball, Joanna (2017). "Why we need to find time for digital humanities: presenting a new partnership model at the University of Sussex». Insights, 2017, 30(3), p. 38-43.

<https://insights.uksg.org/articles/10.1629/uksg.377/>.

Martínez, Dídac (2020). "La biblioteca universitaria: el tercer lugar». Universidad. El blog de Studia XXI, 28 de gener.

<https://www.universidadsi.es/la-biblioteca-universitaria-el-tercer-lugar/>.

Nauta, Gerhard Jan; Heuvel, Wietske van den; Teunisse, Stephanie (2017). Europeana DSI 2- Access to Digital Resources of European Heritage, D4.4. Report on ENUMERATE Core Survey 4. [S.I. : S.n.].

$<$ https://pro.europeana.eu/files/Europeana Professional/Projects/Project list/ENUMERATE/deliverables/DSI-

2 Deliverable\%20D4.4 Europeana Report\%20on\%20ENUMERATE\%20Core \%20Survey\%204.pdf>.

Observatori de Dades Culturals de Barcelona (2018). «Arxius i biblioteques patrimonials». Barcelona: Ajuntament de Barcelona.

$<$ https://barcelonadadescultura.bcn.cat/arxius-i-biblioteques-

patrimonials/dades/>.

«El sentit de la innovació a les biblioteques» (2019). Document: Butlletí del Col-legi Oficial de Documentalistes de Catalunya, 28 de novembre.

$<$ http://www.cobdc.net/document/editorials/sentit-innovacio-

biblioteques/>.

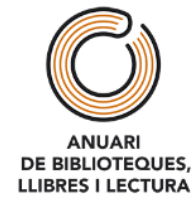


Tramullas, Jesús (2015). «Biblioteques, arxius i museus: reis del GLAM?». Blok de BiD. 18 de novembre.

$<$ http://www.ub.edu/blokdebid/ca/content/biblioteques-arxius-i-museusreis-del-glam>.

Vivó Boada, Lourdes (2018). "Les biblioteques Especialitzades de la Generalitat de Catalunya». Jornada CCUC 2018: projectes i serveis bibliotecaris cooperatius. [Barcelona: Ateneu Barcelonès, 19 d'octubre de 2018].

<https://www.slideshare.net/CSUC info/les-biblioteques-especialitzadesde-la-generalitat-de-catalunya $>$.

Wilms, Lotte; Derven, Caleb; O'Dwyer, Liam; Lingstadt, Kirsty; Verbeke, Demmy (2019). Europe's Digital Humanities Landscape: A Report from LIBER's Digital Humanities \& Digital Cultural Heritage Working Group. [S.I.]: Zenodo. <http://doi.org/10.5281/zenodo.3247286>.

Per a la redacció d'aquest article també s'han consultat les memòries del anys 2018 i 2019 de les institucions següents: Arxiu i Biblioteca del Seminari de Girona, Ateneu Barcelonès, Biblioteca de Catalunya, Biblioteca de la Universitat de Girona, Biblioteca Museu Víctor Balaguer, Biblioteca Pública Arús, Biblioteca Pública Episcopal de Barcelona, Centre de Documentació i Museu de les Arts Escèniques, Consorci de Serveis Universitaris de Catalunya (CSUC), CRAI Biblioteca de Reserva de la Universitat de Barcelona, CRAI Biblioteca del Pavelló de la República de la Universitat de Barcelona, Institut Cartogràfic de Catalunya, Observatori de l'Ebre, Servei de Biblioteques de la Universitat Autònoma de Barcelona i Servei de Biblioteques, Publicacions i Arxius de la Universitat Politècnica de Catalunya.

\section{ANNEX A: CONGRESSOS, SEMINARIS I REUNIONS ESPECÍFIQUES}

- I Jornades d'Humanitats Digitals de la UAB. Universitat Autònoma de Barcelona, 18, 19 i 20 d'abril de 2018.

- 7a Jornada de Museus, Gestió Documental i Arxiu: El poder de les dades en la transformació digital de la cultura. Museu Marítim de Barcelona, 18 d'abril de 2018.

- Segona trobada professional de biblioteques públiques i biblioteca universitària de l'àmbit gironí: Els fons patrimonials $i$ arxivístics. Organitzada per les Biblioteques de la Diputació de Girona, Biblioteques de Girona i Biblioteca de la Universitat de Girona. Biblioteca Pública Carles Rahola (Girona), 2 de juliol de 2018. $<$ https://dugi-doc.udg.edu/handle/10256/15777>.

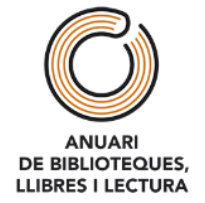


- Fòrum Edita III Trobada del Ilibre i l'edició. Organitzat pel Gremi d'Editors de Catalunya y la UPF Barcelona School of Management i amb el suport de diferents institucions públiques en l'àmbit de la Cultura. Universitat Pompeu Fabra (Barcelona), 4-6 de juliol de 2018.

- IX Encuentro de Centros de Documentación de Arte Contemporáneo: Explotación, integración y difusión del conocimiento de las instituciones patrimoniales". El CSUC hi va participar per tractar sobre Ciència Oberta i les Humanitats Digitals. Vitoria-Gasteiz, Museu Artium, de 2425 d'octubre de 2018.

- 1 eres Jornades sobre el Patrimoni Sonor i Audiovisual. Barcelona, Biblioteca de Catalunya i Arxiu Nacional de Catalunya, 25-26 d'octubre de 2018.

- $\quad$ Jornada sobre Biblioteques Patrimonials: Com aconseguir impacte transformador des d'un centre patrimonial?. Barcelona, Ateneu Barcelonès, 15 de novembre de 2018.

- IV Jornades d'Història de l'Edició a la Facultat. Facultat d'Informació i Mitjans Audiovisuals (Universitat de Barcelona), 19-20 de maig de 2019.

- FOLIO: el futur de les biblioteques és obert. Organitzada pel grup de treball de programari lliure del COBDC, EBSCO i la Comunitat FOLIO. Universitat Pompeu Fabra (Barcelona), 21 de maig de 2019.

- $\Perp$ Jornadas de Patrimonio Bibliográfico Organitzades per REBIUN. Universidad de Santiago de Compostela, 6 i 7 juny 2019.

- Jornada Intensiu Digital: intercanvi d'experiències en col-leccions digitals 2019. Facultat d'Informació i Mitjans Audiovisuals (Universitat de Barcelona), 13 juny 2019.

- 4 t Congreso ISKO España-Portugal (14è d'ISKO España): Organització del coneixement per a l'explotació de col-leccions patrimonials i arxius audiovisuals. Facultat d'Informació i Mitjans Audiovisuals (Universitat de Barcelona), 11-12 de juliol de 2019.

- V Trobada de Fotografia a Museus, Arxius i Biblioteques. Barcelona, Museu Marítim de Barcelona, 15 d'octubre de 2019.

- El patrimoni bibliogràfic, a debat. Taula rodona organitzada pel Grup de recerca EXEMPLAR i amb la participació de Vinyet Panyella, Victoria Rodrigo i Yolanda Ruiz, i coordinació de Concepción Rodríguez Parada. Barcelona. Facultat d'Informació i Mitjans Audiovisuals, 10 desembre 2019. 


\section{ANNEX B: EXPOSICIONS i ACTIVITATS DE DIFUSIÓ}

\section{Exposicions}

\section{8}

- Els plaers de mirar. Tresors del fons bibliogràfic de la Universitat de Barcelona. Museu d'Història de Catalunya. Del 16 de novembre de 2017 al 25 de febrer de 2018.

- Cartografiar per dominar: mapes francesos de la Biblioteca de Montserrat: de la Guerra del francès (1080-1814) a la invasió dels cent mil fills de Sant Lluís (1823). Biblioteca de l'Abadia de Montserrat. De gener a maig de 2018.

- El fons de segells pendents de pergamins de la BC. Biblioteca de Catalunya, Espai Zero. Del 15 de gener al 14 de febrer de 2018.

- Biblioteques insòlites. Centre d'Art Santa Mònica. Del 30 de gener al 23 d'abril de 2018.

- Els Torelló d'Igualada. II.lustre Col·legi d'Advocats de Barcelona. Del 16 de febrer al 23 de març de 2018.

- Jornada de portes obertes a les restauracions dels tresors del CDMAE. Centre de Documentació i Museu de les Arts Escèniques. 20 de febrer de 2018.

- Arxius de dones. CRAI Biblioteca de Biblioteconomia i Documentació (Universitat de Barcelona). Març de 2018.

- Pompeu Fabra, el lingüista modern. Ateneu Barcelonès. Abril de 2018.

- La Història moral de Cathalunya del jesuïta Pere Gil (1550-1622): Una obra teològica en la Barcelona confessional del tombant del segle XVIXVII. Biblioteca Pública Episcopal de Barcelona. Del 16 d'abril al 22 de juny de 2018.

- Imatges del Quixot. CRAI Biblioteca de Lletres i CRAI Biblioteca de Reserva (Universitat de Barcelona). Del 20 d'abril al 4 de maig de 2018.

- Els incunables, del còdex manuscrit al llibre tipogràfic modern. Biblioteca de Catalunya, Espai Zero. Del 16 de maig al 16 de juny de 2018.

- Prelum celebratissimum, la premsa tipogràfica més festejada. CRAI Biblioteca de Reserva (Universitat de Barcelona). Del 4 al 29 de juny de 2018. 
- Pau Audouard: el fotògraf artista. Biblioteca de Catalunya, Sala d'exposicions. Del 7 de juny al 7 d'agost de 2018.

- Les dones i les Ileis. II-lustre Col-legi d'Advocats de Barcelona. Del 9 de juliol al 9 d'octubre de 2018.

- Samuel Gili Gaya: la pedagogia incontestable. Universitat de Lleida. Del 3 de setembre al 24 d'octubre del 2018.

- Barcelona, ciutat de setges. Biblioteca de Catalunya, Espai Zero. Del 13 de setembre al 15 d'octubre de 2018.

- Joan Solà, bibliòfil. CRAI Biblioteca de Lletres i CRAI Biblioteca de Reserva (Universitat de Barcelona). Del 17 de setembre al 31 octubre de 2018.

- Impressions Mompou. Biblioteca de Catalunya, Espai Zero. Del 16 d'octubre al 15 de novembre de 2018.

- Els ex-libris i les marques d'impressor. Biblioteca Pública de Girona Carles Rahola. Del 18 d'octubre al 3 de noviembre de 2018.

- Aquells pupitres de fusta. Biblioteca de Cappont, Universitat de Lleida. Del 30 d'octubre del 2018 a l'1 de febrer del 2019.

- Tricentenari de la mort de Pau Ignasi de Dalmases: en el seu temps amb els seus llibres. CRAI Biblioteca de Reserva (Universitat de Barcelona). Del 5 de novembre al 28 de novembre de 2018.

- Exposició bibliogràfica virtual "Homenatge a Josep Fontana". Biblioteca (Universitat Pompeu Fabra). Del 16 de novembre al 2 de desembre de 2018.

El Palau dels Palau: de les fitxes a les edicions del Manual. Facultat de Biblioteconomia i Documentació (Universitat de Barcelona). De novembre a desembre de 2018.

Paradisini, marques tipogràfiques al jardí. CRAI Biblioteca de Reserva (Universitat de Barcelona). Del 3 de desembre de 2018 a l'11 de gener de 2019.

\section{9}

- Fons musicals patrimonials, dels missals a les partitures de Baró. Biblioteca Pública de Girona Carles Rahola. Gener-Febrer de 2019.

Dones a la Palestra de l'Ateneu Barcelonès. Ateneu Barcelonès. De gener a mitjans d'abril de 2019. 
- D'Orient a Occident. CRAI Biblioteca de Reserva (Universitat de Barcelona). Del 15 de gener al 27 de febrer de 2019.

- "El noble esforç": I'herència dels trobadors a Catalunya. Biblioteca de Catalunya, Sala d'Exposicions. Del 21 de febrer al 25 d'abril de 2019.

- La Mediterrània: una mirada des del fons antic [dins el marc del festival MOT]. Biblioteca Pública de Girona Carles Rahola. Del 13 de març al 30 de juny de 2019.

- Lletraferides republicanes. Biblioteca de Catalunya, Espai Zero. Del 18 de març al 27 d'abril de 2019.

- A pot petit... Llibres miniatura i microscòpics a la BC. Biblioteca de Catalunya, Espai Zero. Del 18 d'abril al 18 de maig de 2019.

- Les aigües en moviment: una visió jurídico-històrica. Biblioteca de I'Il-lustre Col·legi d'Advocats de Barcelona. Març de 2019.

- D'llíades i Odissees. CRAI Biblioteca de Lletres i CRAI Biblioteca de Reserva (Universitat de Barcelona). De l'11 de març al 5 d'abril de 2019.

- Rotlles de pianola. Biblioteca d'Humanitats en col·laboració amb el Grup de Treball "Les Músiques de Reproducció Tecnològica" del Departament d'Art i Musicologia de la UAB. Abril 2019.

- La correspondència al món editorial: segles XIX-XX. Facultat de Biblioteconomia i Documentació (Universitat de Barcelona). Del 2 al 31 de maig de 2019.

Cultura i progrés: els tresors de la Biblioteca del Centre de Lectura. Centre de Lectura de Reus. Del 9 de maig al 15 de juny de 2019.

- Música antiga: alguns exemples de llibres de música del fons antic de la Biblioteca. Biblioteca Pública de Girona Carles Rahola. Del 17 de maig al 23 de juliol de 2019.

- La bibliofília a Catalunya. Biblioteca de Catalunya, Sala d'Exposicions. Del 31 de maig al 31 de juliol de 2019.

- Ephemera: els materials impresos efímers. Barcelona, Facultat de Biblioteconomia i Documentació, 1-21 de juny de 2019. Alumnes de I'assignatura sobre "Material Ephemera" impartida per Pedro Rueda, del Màster de Biblioteques i Col-leccions Patrimonials.

Pepita Texidor. CRAI Biblioteca de Reserva (Universitat de Barcelona). Del 4 de juny al 12 de juliol de 2019.

Tipus, éssers i barruts. CRAI Biblioteca de Reserva (Universitat de Barcelona). Del 20 de juny al 12 de juliol de 2019.

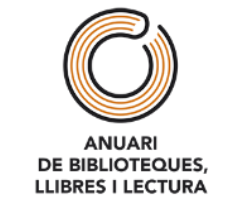


- 150 anys de la targeta postal. Ateneu Barcelonès. Setembre de 2019.

- L'enquadernació: una mirada diferent del llibre antic. Biblioteca Pública de Girona Carles Rahola. Setembre-Desembre 2019.

150 anys del Col-legi d'Arquitectes de Catalunya. Barcelona, Arxiu Històric del Collegi d'Arquitectes de Catalunya. Del 7 d'octubre de 2019 al 7 de gener de 2020 .

- Joaquim Miret i Sans (1858-1919). Una vida dedicada al patrimoni català. Biblioteca de Catalunya, Espai Zero. Del 18 de desembre al 22 de gener de 2020.

- La vida privada dels llibres. CRAI Biblioteca de Reserva (Universitat de Barcelona). De l'11 de desembre de 2019 al 28 de febrer de 2020.

\section{Activitats de difusió}

De les visites adreçades a professionals organitzades pel Col-legi de Bibliotecaris i Documentalistes de Catalunya, en destaquem les relatives a centres patrimonials:

- Biblioteca de l'Il-lustre Col-legi de l'Advocacia de Barcelona, 26 de març de 2018.

- Biblioteca del Cinema, 29 de juny de 2018.

- Centre de documentació del Museu de Ciències Naturals de Barcelona, 30 de gener de 2019.

- Biblioteca de l'll|lustre Col-legi de l'Advocacia de Barcelona, 9 de febrer $\mathrm{i}$ 4 de juny de 2019.

- Biblioteca Pública Carles Rahola de Girona, 21 de març de 2019.

- Biblioteca Pública Arús, 20 de juny de 2019.

- Biblioteca Joaquim Folch i Torres del MNAC, 16 de setembre de 2019.

- INSPAI, Centre de la Imatge de la Diputació de Girona, 27 de novembre de 2019.

- Arxiu històric del Col·legi d'Arquitectes de Catalunya, 16 de desembre de 2019. 


\section{ANNEX C: PARTICIPACIONS EN CONGRESSOS I PUBLICACIONS}

\section{Biblioteques patrimonials}

Altarriba, Núria, dir. (2018). The Troubadours to Ausiàs March: heritage of the Biblioteca of Catalunya. Barcelona: Biblioteca de Catalunya (Escrits i memòria. Anglès; 4). <https://botiga.bnc.cat/?product=the-troubadours-toausias-march-heritage-of-the-biblioteca-de-catalunya>.

Artiga, Alfred; Basomba, Georgina; Gil, Marta; Isern, Concepció; Ramos, Noèlia; Serarols, Montserrat (2018). "Adopción de las normas de catalogación RDA al catálogo colectivo de las universidades catalanas». VIIIè congrés biennal d'IBERCARTO. Portugal, Universitat de Porto, 15-17 de novembre.

$<$ https://www.fc.up.pt/biblioteca/ibercarto/storage/docs/programa/adopci on-de-las-normas-de-catalogacion-rda-al-catalogo-colectivo-de-lasuniversidades-catalanas.pdf $>$.

Barbé Aragonès, Cristina (2018). "Patrimoni bibliogràfic i mecenatge». Revista del Centre de Lectura de Reus, 19 de setembre.

$<$ https://www.centrelectura.cat/revistadigital/patrimoni-bibliografic-imecenatge/>.

Bruch, Araceli; Julià, Lluïsa (2019). Cartografies del desig III. Sis espectacles de teatre de cambra. Barcelona: Departament de Cultura; Biblioteca de Catalunya. $<$ https://botiga.bnc.cat/?product=cartografies-del-desig-iii $>$.

Caballer Albareda, Gemma (2019). «De guardianes a gestores: el valor del patrimonio bibliográfico del CRAI Biblioteca de Reserva de la Universidad de Barcelona como activo en docencia y en investigación». II Jornadas de Gestión del Patrimonio Bibliográfico. Universidad de Santiago de Compostela, Facultad de Medicina. 6 i 7 de juny de 2019.

$<$ http://hdl.handle.net/2445/136718>.

Caballer Albareda, Gemma (2019). "Dos anys d'activisme en formació: l'experiència del CRAI Biblioteca de Reserva». 7a Jornada de Bones Pràctiques: Formació d'usuaris (CRAI UB), 16 de juliol de 2019. <http://diposit.ub.edu/dspace/handle/2445/137659>.

Caballer Albareda, Gemma; Moré, Laura; Muxella, Imma; Nicolau Payàs, Anna (2018). "Biblioteques patrimonials a Catalunya (2016-2017)». Anuari de l'Observatori de Biblioteques, Llibres i Lectura. vol. 5, p. 186-216. <https://www.raco.cat/index.php/AnuariObservatori/article/view/350713 >

Comas, Montserrat (2018). "Els centres de patrimoni literari com a recurs educatiu. El cas de la Biblioteca Museu Víctor Balaguer i el fons Joaquim Molas». Xerrada i visita a la Biblioteca Museu Víctor Balaguer organitzades per Xarxa del patrimoni literari català. Vilanova i la Geltrú, 14 d'octubre. 
Corbella i Corbella, Jacint; Cama Socías, Daniel; Jaular Aulet, Irene; Alpañez López, M. Carmen (2019). «El fil per a cosir la història ... ... de la medicina: exposició: Recull del fons antic del CRAI Biblioteca Campus Clínic, generabril 2019». Gimbernat: Revista Catalana d'Història de la Medicina i de la Ciència, vol. 71. <http://hdl.handle.net/2445/134557> .

Cuerva, Pilar (2018). "La integració de la informació digital amb Alfresco al Museu Marítim de Barcelona». 7a Jornada de Programari Lliure per a Unitats d'Informació. Barcelona, Grup de Programari Lliure del COBDC, 18 de maig.

$<\underline{\text { https://www.slideshare.net/gtprogramari/la-integraci-de-la-informaci- }}$ digital-amb-alfresco-al-museu-martim-de-barcelona>.

Ezquerra, Xavier; Moré, Laura; Rufí, Jaume (2019). «Bertrana de Capçalera, un proyecto de humanidades digitales». II Jornadas de Gestión del Patrimonio Bibliográfico. Universitat de Santiago de Compostela, Facultad de Medicina. 6 y 7 de junio de 2019.

<http://hdl.handle.net/20.500.11967/382>.

Fullà, Núria (2019). «El Patrimoni Bibliogràfic de Catalunya i els centres que la custodien». Blog de la Biblioteca de Catalunya. 18 de setembre. $<$ http://www.bnc.cat/El-Blog-de-la-BC/El-Patrimoni-Bibliografic-de-

Catalunya-i-els-centres-que-el-custodien>.

Gras Casanovas, Mercè (2019). "Los libros y sus lectoras: la biblioteca conventual en el Carmelo descalzo femenino». Congresso Internacional "Um Reino de Mulheres", Universidad de Evora (Portugal), 24 d'abril.

Gras Casanovas, Mercè (2018). «Tres homes d'acció, tres biblioteques: Dalmases, Aparici, Martí». Xerrada en el marc de les jornades amb motiu del Tricentenari de la mort de Pau Ignasi de Dalmases (1670-1718), CRAI Biblioteca de Reserva de la Universitat de Barcelona, 15 de novembre.

Guasteví, Sara (2018). "L'Espai de Documentació i Recerca del Museu de la Música de Catalunya». Sonograma Magazine. Revista de Pensament musical i difusió cultural, 23 d'abril.

$<$ http://sonograma.org/2018/04/lespai-de-documentacio-i-recerca-delmuseu-de-la-musica-de-barcelona/>.

Gudayol, Anna (2018). "La col-lecció Dalmases a la Biblioteca de Catalunya». Xerrada en el marc de les jornades amb motiu del Tricentenari de la mort de Pau Ignasi de Dalmases (1670-1718), CRAI Biblioteca de Reserva de la Universitat de Barcelona, 15 de novembre.

Gudayol, Anna (2019). «El fons Deffontaines a la Biblioteca de Catalunya». Barcelona, Societat Catalana de Geografia, 19 de novembre.

$<$ https://www.slideshare.net/BibliotecaCatalunva/2019-iecscgeografiadeffontainesbc $>$

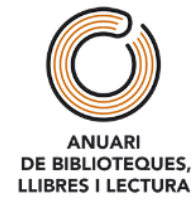


Gudayol, Anna (2019). "Les amitiés catalanes de Mistral: lettres et livres à la Biblioteca de Catalunya». Colloque International Centre Aixois d'Études Romanes (CAER), 10-12 d'octubre.

$<$ https://www.slideshare.net/BibliotecaCatalunya/les-amitis-catalanes-demistral-lettres-et-livres-la-biblioteca-de-catalunya>.

Jorba, Ferran; Santos, Teresa; Azorín, Cristina (2018). «La gestió digital de la col-lecció de cartells polítics a la UAB». 15es Jornades Catalanes d'Informació i Documentació, Barcelona, 10-11 de maig.

$<$ http://www.cobdc.net/15JCID/wpf>.

Mañà, Teresa (2018). "El començ d'una vida nova: el projecte de biblioteques populars de la Mancomunitat de Catalunya». Valls, Biblioteca Pública de Valls, 23 de maig de 2018.

Montes, Sergio (2018). "La implementació de Koha a la biblioteca de l'Ateneu Barcelonès». 7a Jornada de Programari Lliure per a Unitats d'Informació. Barcelona, Grup de Programari Lliure del COBDC, 18 de maig. $<$ https://www.slideshare.net/gtprogramari/el-canvi-de-sistema-de-gestibibliotecria-reptes-i-oportunitats-la-implementaci-de-koha-a-la-bibliotecade-lateneu-barcelons>.

Oviedo Sánchez, Míriam (2018). «El fons patrimonial de la Biblioteca Pública de Girona Carles Rahola: una aproximació a la gestió de les col-leccions i els serveis». Ítem Revista de biblioteconomia i documentació, núm. 64 (generjuny), p. 90-106.

<https://www.raco.cat/index.php/Item/article/view/341733/432585>.

Prades Artigas, M. Lourdes (2018). «Recuperem la història dels Brigadistes. Presentació de la plataforma SIDBRINT, un projecte viu». Seminari internacional 1938-2018. Història i memòria de les Brigades Internacionals. Una mirada est-oest, Universitat de Barcelona. 26 d'octubre de 2018.

Prades Artigas, M. Lourdes (2019). "Cultural memory of the Spanish Civil War». International Conference "The battle for Spain is Ours: Collective Memory of the International Brigades in Rijeka", Universitat de Rijeka (Croàcia). 6 de juny de 2019.

Rodrigo Fuentes, Victoria; Ruiz Ruiz, Yolanda (2019). De tesoros a bienes patrimoniales: la difusión del patrimonio bibliográfico. Gijon: Ediciones Trea (Biblioteconomía y documentación).

Ruiz Fargas, Marina (2018). «Presentació de la col·lecció Dalmases conservada a la UB». Xerrada en el marc de les jornades amb motiu del Tricentenari de la mort de Pau Ignasi de Dalmases (1670-1718), CRAI Biblioteca de Reserva de la Universitat de Barcelona, 15 de novembre. 
Ruiz Fargas, Marina; Verger, Neus (2019). «Dels convents a l'acadèmia: els orígens de la biblioteca de la Universitat de Barcelona (1835-1881)». A: Elias Rogent i Barcelona: arquitectura, patrimoni i restauració. Barcelona: Edicions de la Universitat de Barcelona.

<http://diposit.ub.edu/dspace/handle/2445/121374>.

Ruiz Fargas, Marina (2019). "Estada a la Biblioteca de Catalunya». 8a Jornada de Bones Pràctiques: Estades en institucions del CSUC (CRAI UB). 26 de novembre de 2019. Sala d'actes de la Facultat d'Informació i Mitjans Audiovisuals de la Universitat de Barcelona.

<http://hdl.handle.net/2445/146281>.

Serra, Eugènia (2019). "Google Llibres 12 anys després». Intensiu Digital 2019: Jornada d'intercanvi d'experiències en col-leccions digitals. Barcelona (13 de juny). <https://www.slideshare.net/FBDUB/google-llibres-12-anysdesprs>.

Ullate, Margarida (2019). "Els documents sonors: Les seves característiques i la seva preservació: nous reptes». IV Jornada d'Arxius (2 de maig). $<$ https://www.slideshare.net/BibliotecaCatalunya/els-documents-sonorsles-seves-caracterstiques-i-la-seva-preservaci>.

Ullate, Margarida; Pérez, Karibel (2019). «Els objectes sonors digitals al repositori COFRE de la BC: recollir, descriure, preservar i donar accés». Jornades sobre el Patrimoni Sonor i Audiovisual, 24 d'octubre. . $<$ http://www.bnc.cat/content/download/116376/1738286/version/1/file/P resentaci\%C3\%B3 BC KP MUEdef+\%281\%29.pps >.

Verger, Neus (2018). "Las portadas sueltas del CRAI Biblioteca de Reserva». Ponència a "Libris satiari nequeo". De la Edad Media a la Era Digital. València, 24 al 26 de gener del 2018. <http://hdl.handle.net/2445/119374>.

Verger, Neus (2018). "The Printers' Devices database of the University of Barcelona. A resource for the study of printers' devices». Comunicació a Typography, illustration and ornamentation in the Early Modern Iberian Book World, 1450-1800. 24 i 25 de maig de 2018, Marsh's library, Dublin. <http://hdl.handle.net/2445/122666>.

Verger, Neus (2018). «Els Ilibres antics de la Universitat de Barcelona: una col-lecció per descobrir». Xerrada a la Reial Acadèmia de Farmàcia, 24 d'octubre.

Verger, Neus (2018). «Passat, present i futur de la base de dades Marques d'Impressors». Xerrada en el marc de l'exposició Paradisini, marques tipogràfiques al jardí, CRAI Biblioteca de Reserva de la Universitat de Barcelona, 4 de desembre. 


\section{Història del llibre i de la impremta}

Altarriba, Núria; Corbeto, Albert; Hartmann, Wolfgang (2018). Conferència "Els incunables, del còdex manuscrit al Ilibre tipogràfic modern». Biblioteca de Catalunya, 31 de maig.

Biblioteca de Catalunya; Associació de Bibliòfils de Catalunya (2019). Cicle de conferències "Bibliofília i col·leccionisme del llibre a Catalunya, segles XIX-XXI". Barcelona, juny 2019.

Botanch, Eduard (2018). «Marques tipogràfiques, els primers logos del món editorial». Xerrada en el marc de l'exposició Paradisini, marques tipogràfiques al jardí, CRAI Biblioteca de Reserva de la Universitat de Barcelona, 4 de desembre.

Camprubí, Xevi (2018). L'Impressor Rafael Figueró (1642-1726) i la premsa a la Catalunya del seu temps. Barcelona: Fundació Noguera.

Carpallo Bautista, Antonio; Flores Hernández, Yohana Yessica (2018). «La Catedral de Toledo en el segle XVII: anàlisi documental de les enquadernacions de tipus ventalls». BiD Textos universitaris de biblioteconomia i documentació, núm. 41 (desembre).

<http://bid.ub.edu/41/carpallo.htm>.

Escobedo, Joana (2018). «Joan Maragall i els goigs de Núria». Haidé: estudis maragallians: butlletí de l'Arxiu Joan Maragall, núm. 7, p. 105-170. <https://raco.pre.csuc.cat/index.php/Haide/article/view/347603/439037>.

Fernández-Rincón, Antonio-Raúl; Hellín, Pedro; Gómez Hernández, José Antonio (2018). «A I'Imperi de la Cultura: ús publicitari de biblioteques i patrimoni bibliogràfic en el Noticiero Documental (NO-DO) durant la dictadura de Franco, 1939-1975». BiD: Textos universitaris de biblioteconomia i documentació, núm. 41 (desembre).

<http://bid.ub.edu/41/zaldua.htm>.

Gudayol, Anna (2019). «Sobre la importancia de la bibliografía material en la reconstitución virtual de bibliotecas humanistas e ilustradas: manuscritos de Zurita en la Biblioteca de Cataluña». XX Jornadas de Trabajo de la Asociación Española de Bibliografía, en col·laboració amb la Biblioteca Nacional de España. Madrid, 27 i 28 de novembre.

Pintó, Roser, presentació i selecció (2019). Cartells catalans. Art, literatura i música: 1888-2018. Barcelona: Grup Enciclopèdia Catalana.

Reyes Gómez, Fermín de los (2018). «Incunables: certezas, enigmas e insólitos hallazgos». Conferència a la Facultat d’Informació i Mitjans Audiovisuals (UB). Barcelona, 19 de desembre.

Rius i Bou, Àngels (2018). «Cartografiar per dominar: la invasió dels Cent Mil Fills de Sant Lluís (1823) en els mapes francesos de la Biblioteca de Montserrat». Montserrat: Butlletí del Santuari, núm. 110, p. 60-68. 
Rius i Bou, Àngels (2018). «Darrere les petjades de Gutenberg: la impremta incunable de Montserrat (1499-1500)». Montserrat: Butlletí del Santuari, núm. 111, p. 63-68.

Rius Bou, Àngels (2019). "Biblioteca e imprenta en el hospital militar de Montserrat (1938-1939)». XX Jornadas de Trabajo de la Asociación Española de Bibliografía, en collaboració amb la Biblioteca Nacional de España. Madrid, 27 i 28 de novembre.

Rius i Bou, Àngels (2019). «Darrere les petjades de Gutenberg : la impremta de Montserrat des de 1501 a 1524». Montserrat: Butlletí del Santuari, núm. 114, p. 53-59.

Rueda, Pedro (2018). "Libros raros en los inicios del mercado del libro antiguo en España (1750-1840)». Rareté et livres rares du XVe au XXle siècle". Université de Rennes, 5-6 d'abril.

Rueda, Pedro (2019). «Trataditos devotos: impresos para las misiones franciscanas de Escornalbou en la Cataluña moderna». XX Jornadas de Trabajo de la Asociación Española de Bibliografía, en col·laboració amb la Biblioteca Nacional de España. Madrid, 27 i 28 de novembre.

Rueda, Pedro (2019). «Una hoja volante de publicidad del libro: el Memorial de las impressions y estampas per avivar las memorias del Novíssims, y camins de la eternitat (Barcelona, s.a.)». XX Jornadas de Trabajo de la Asociación Española de Bibliografía, en col·laboració amb la Biblioteca Nacional de España. Madrid, 27 i 28 de novembre.

Rueda, Pedro; Planas, Josefina; Iglesias-Fonseca, J.A.; Llavata, Mandingorra; Verger, Neus (2018). Taula rodona «Libros perdidos, fragmentos, inventarios...». Libris satiari nequeo. De la Edad Media a la Era Digital. València, Universitat de València, 24-26 de gener de 2019.

Rueda, Pedro; Saumell, Dolors (2019). "Les marques de propietat dels llibres de la Biblioteca d'Escornalbou: un patrimoni recuperat». Ítem: Revista de biblioteconomia i documentació, núm. 65-66.

< https://www.raco.cat/index.php/Item/article/view/353620/444643 >.

Solé Boladeras, Isaura (2019). "Las revistas sobre el arte de la imprenta en la Barcelona de la segunda mitad del siglo XIX. ¿Difusión de avances técnicos u órgano publicitario?». XX Jornadas de Trabajo de la Asociación Española de Bibliografía, en col·laboració amb la Biblioteca Nacional de España. Madrid, 27 i 28 de novembre.

Xarxa d'Arxius Comarcals (2018). "Un petit recull de les característiques més comunes del llibre antic». Web del Departament de Cultura de la Generalitat de Catalunya, 4 de setembre.

<http://xac.gencat.cat/ca/detalls/Noticia/El-Ilibre-antic>. 


\section{Publicacions tècniques i normativa}

Biblioteca de I'ICAB (2018). Reglament. Barcelona, ICAB, juny. $<$ www.icab.cat/files/242-499659DOCUMENTO/REGLAMENT\%20APROVAT\%20BIBLIOTECA.pdf>.

Boté, Juanjo (2019). "Dataset management as a special collection». Collection Management, vol. 24, issue 2-4.

<DOI: 10.1080/01462679.2019.1586613>

Franganillo, Jorge (2018). Gestión de información personal: integración mediante el correo electrónico. Barcelona: UOC. 174 p.

Grup de Treball de Reserva del COBDC (2019). "Pautes en RDA de col-leccions especials i fons personals». Barcelona, CSUC.

$<$ https://confluence.csuc.cat/pages/viewpage.action?pageld=29361335>.

Universitat Autònoma de Barcelona (2018). Política de preservació del repositori institucional. Bellaterra, Servei de Biblioteques de la UAB. $<$ https://ddd.uab.cat/record/189808>.

Universitat de Girona. Biblioteca (2019). Pla de gestió de la col-lecció de la Biblioteca de la Universitat de Girona. Girona, Biblioteca UdG. $<$ http://hdl.handle.net/10256/16665> (inclou un apartat que actualitza les pautes d'acceptació de donatius).

\section{Publicacions sobre els fons patrimonials}

Alforja Carbonell, Enric (2019). «L'Espai Joan Fuster de Sueca». Símile, núm. 43 (2a època setembre). <http://cobdcv.es/simile/lespai-joan-fuster-asueca/>.

Allué, Alícia (2019). «Les portades soltes de Barcelona: una nova aproximació». Blog de Reserva, 17 de juliol.

$<$ https://blocbibreserva.ub.edu/2019/07/17/les-portades-soltes-debarcelona-una-nova-aproximacio/>.

Alturo, Jesús; Alaix, Tània (2019). «La presentació de l'edició de les Chartae Latinae Antiquiores Cataloniae». Bonart, 14 de novembre. $<$ https://www.bonart.cat/actual/presentacio-de-ledicio-de-les-chartaelatinae-antiquiores-cataloniae/>.

Andreu, Jordi (2019). "Archivo Histórico de Banco Sabadell (AHBS): Constitución e integración de fondos»; taula rodona per a la presentació de la Guía de Archivos Históricos de la Banca en España. Madrid, Banco de España, 16 de juliol.

Asensio Bestraten, Emma; Navarro Codina, Montserrat; Navas-Fernández, Miguel (2019). «El Centro de Documentación del Museu de Ciències

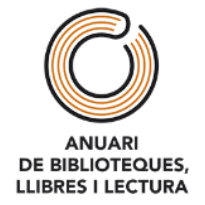


Naturals de Barcelona: la importancia de la difusión en Internet de colecciones y publicaciones». XXIII Bienal de la Real Sociedad Española de Historia Natural. Barcelona, 5-6 de setembre.

<https://www.recercat.cat/bitstream/handle/2072/366991/XXIII Bienal RS EHN Asensio.pdf?sequence $=1>$.

Bastardas, Maria Reina; Auladell, Cristina; Barba, Anna. "Un imprès desconegut d'"Ogier le Danois" en prosa de 1516 (París, François Regnault)». Estudis Romànics, vol. 41. 2019, p. 475-488.

Batlló Colominas, Roser; Irigoyen, Jaime (2019). “Colección HabanaBarcelona: una experiencia de interoperabilidad y cooperación en materia de patrimonio digital". Ponència. 11 d'octubre de 2019. $<$ https://bcnroc.ajuntament.barcelona.cat/ispui/bitstream/11703/115680/ 1/2019-10-11 La-Habana Barcelona BCNROC.pdf>.

Bertrana, Aurora. (2019). Ara us parlaré: conferències (1930-1967). Edició a cura d'Adriana Bàrcia. Girona: Diputació de Girona. 224 p.

«Dones i arxius: la difusió dels fons de dues intèrprets (Alicia de la Rocha i Victoria de los Ángeles)». Universitat de Barcelona. Facultat d'Informació i Mitjans Audiovisuals. Comissió d'Igualtat (2018). Barcelona, 11 d'abril [taula rodona].

Fossas, Ignasi; Rubio Sadia, Juan Pablo (2019). «El Ms. 880 de la Biblioteca de Montserrat : un breviari romanotoledà del segle XIV». Miscel/lània litúrgica catalana, vol. 27, p. 369-411.

<http://revistes.iec.cat/index.php/MLC/article/viewFile/146193/144716>.

Gil Solés, Daniel (2018). "The printing of popular religious books in Barcelona during the Nineteenth Century». Catholic Library World, vol. 89, no. 2, p. 104-120.

Gros i Pujol, Miquel dels Sants (2018). «Fragments de passioner i del leccionari del santoral de la Biblioteca Episcopal de Vic dels segles IX-XIII». Miscel/lània litúrgica catalana, vol. 26, p. 97-145.

<http://revistes.iec.cat/index.php/MLC/article/viewFile/145277/143899>.

Gudayol, Anna (2019). "L'arribada dels cançoners Vega a la Biblioteca de Catalunya». Plecs d'Història Local, 174 (juliol/agost), p. 8-10.

$<$ https://www.irmu.org/download/plecs/editions/plecs 174 5d247f7c35b4 $\underline{0 . p d f}>$.

Jornet, Núria (2018). "Archival memory in the medieval monasteries: the case of St Antoni i Sta Clara of Barcelona». International Medieval Congress. University of Leeds, 2-5 de juliol.

Jornet, Núria (2019). «Plàcida Genescà i Caballé, una arxivera amb arrels manresanes». Barcelona, Servei d'Arxius de la Federació Catalana de Monges Benedictines i el Centre d'Estudis del Bages, 28 de març.

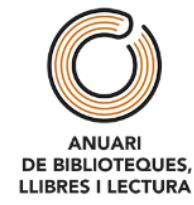


Lian, Jinfa; Zhang, Shuying, ed. (2019). Arte de la lengua chio chiu. [Beijing]: National Tsing Hua University Press.

Martos, Josep Lluís (2019). "Materialitat i errors de composició d’un incunable poètic (b2/87FD): la rendibilitat ecdòtica». Magnificat Cultura $i$ Literatura Medieval, vol 6, p. 165-184.

Martos, Josep Lluís (2019). "Los ejemplares del incunable poético 87FD1». A: Lacarra, Maria Jesús (coord.). Literatura medieval hispánica "Libros, lecturas y reescrituras». San Millán de la Cogolla: Cilengua.

Mistral a Catalunya (2018). Textos i entrevistes: Antoni Rossell i Hélène Rufat; Núria Altarriba, dir. Barcelona: Departament de Cultura de la Generalitat de Catalunya: Biblioteca de Catalunya (Escrits i memòria; 6).

$<$ https://botiga.bnc.cat/?product=mistral-a-catalunya $>$.

Molas, Maria del Tura (2018). "La col·lecció de revistes de subscripció de la Biblioteca de Catalunya». Blog de la Biblioteca de Catalunya, 27 de desembre. <http://www.bnc.cat/El-Blog-de-la-BC/La-col-leccio-de-revistesde-subscripcio-de-la-Biblioteca-de-Catalunya $>$.

Montalt, Rosa, ed. (2018). Emili Salut i Payà, un músic al gulag. Memòries d'Emili Salut i Payà. Barcelona: Biblioteca de Catalunya. 95 p. (Mínima ; 16).

Montalt, Rosa (2018). «Partitures de banda a la Biblioteca de Catalunya, a banda». I Congrés Internacional de la Llum: el patrimoni documental de les bandes de música. Universitat de València, 13 a 15 de desembre. $<$ https://coessm.org/wp-content/uploads/2018/12/Programa-I-CongresoInternacional-M\%C3\%BAsica-a-la-Llum.pdf>.

Navas-Fernández, Miguel; Uribe Porta, Francesc; Folia, Marc (2019). «Òmnimus: un vehículo para conocer y consultar diversas fuentes de datos del Museu de Ciències Naturals de Barcelona». XXIII Bienal de la Real Sociedad Española de Historia Natural. Barcelona, 5-6 de setembre.

"L'ús del fonògraf a l'Obra del Cançoner Popular de Catalunya» (19 de juliol 2018). Guió, direcció i coordinació: Ramon Vilar i Manel Canes Producció audiovisual: Creatiu Digital. <https://youtu.be/G6pGbGefFQs $>$.

\section{Publicacions sobre preservació del patrimoni}

Herrera Morillas, José Luís (2019). «Sobre la conservació del fons antic a les biblioteques regionals de les comunitats autònomes». BiD: Textos universitaris de biblioteconomia i documentació, núm. 43 (desembre). <http://bid.ub.edu/43/herrera.htm>. 
Valls, Anna (2019). “Te'n recordes? Ajuda'ns a documentar les arts escèniques". XVI Jornadas Españolas de Información y Documentación de FESABID. Barcelona, Auditori del World Trade Center, 16-17 de maig de 2019.

$<$ https://www.facebook.com/MaeArtsEsceniques/videos/25011454765762 $\underline{64 />}$.

Vega, Ricard de la (2018). «Technical Challenges and Approaches to Build an Open Ecosystem of Heterogeneous Heritage Collections»; presentació del projecte ECHOES. Congrés Archiving, Lisboa, 14-16 maig.

$<$ https://www.slideshare.net/ECHOES Community/technical-challengesand-approaches-to-build-an-open-ecosystem-of-heterogeneous-heritagecollections-146242191>. 
Disponible a:

https://revistes.ub.edu/index.php/Anuari-BLL/article/view/32754

Caballer Albareda, Gemma; Moré, Laura; Muxella, Imma; Nicolau Payàs, Anna. «Biblioteques patrimonials a Catalunya (2018-2019)». Anuari de Biblioteques, Llibres i Lectura, vol. 6 (2020), p. 135-181. DOI 10.1344/ABLL.2020.6.009

Llicència Creative Commons

Reconeixement - NoComercial - SenseObraDerivada

(by-nc-nd): No es permet un ús comercial de l'obra

original ni la generació d'obres derivades. 


\section{ANUARI}

\section{DE BIBLIOTEQUES, \\ LLIBRES I LECTURA}

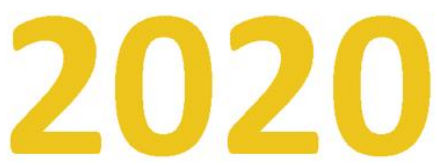

Editors

Lluís Agustí

Maite Comalat

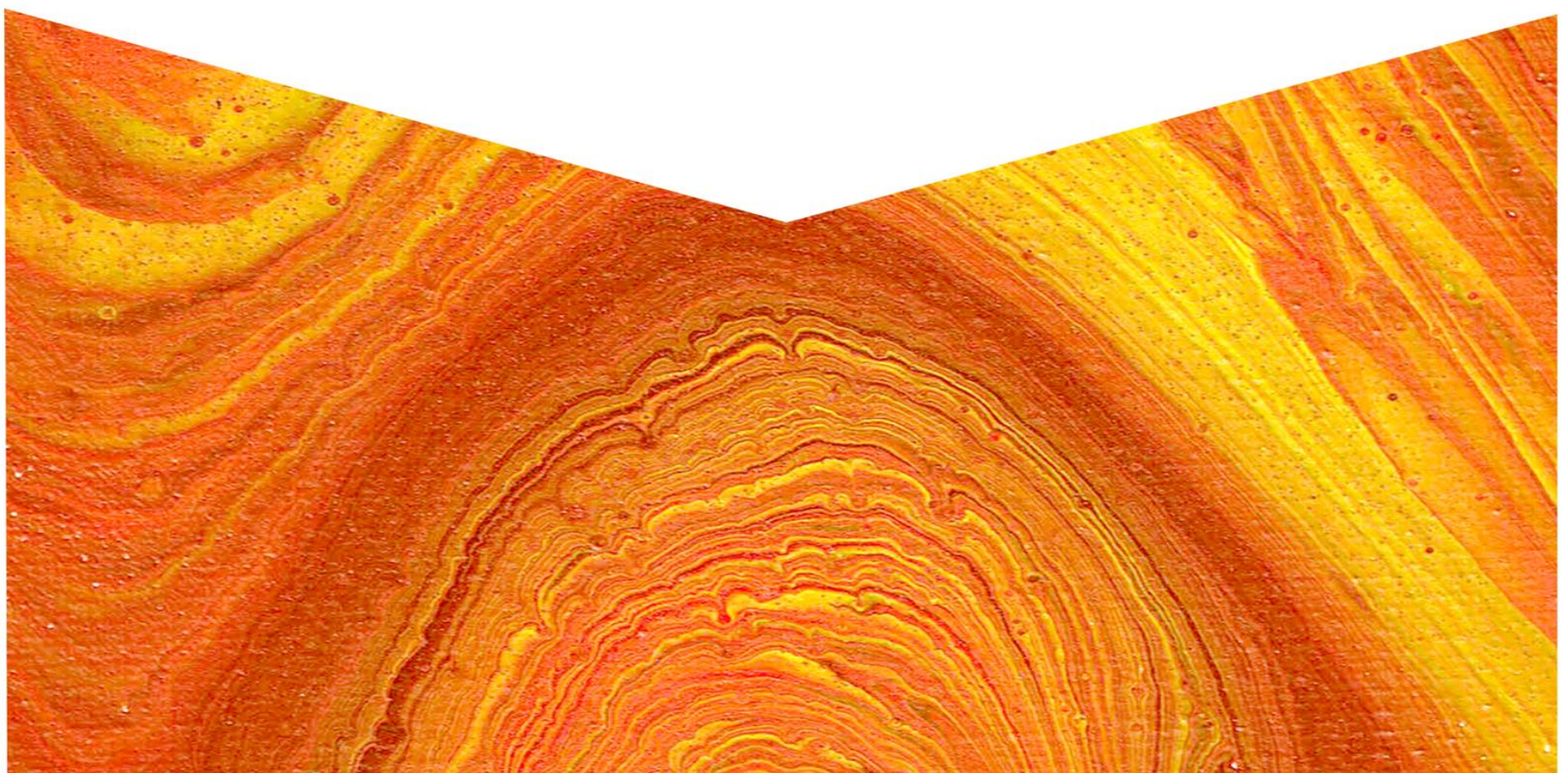

